\title{
24. PALEOMAGNETIC EVIDENCE FOR NORTHWARD DRIFT AND CLOCKWISE ROTATION OF THE IZU-BONIN FOREARC SINCE THE EARLY OLIGOCENE ${ }^{1}$
}

\author{
Masato Koyama, ${ }^{2}$ Stanley M. Cisowski, ${ }^{3}$ and Philippe Pezard ${ }^{4}$
}

\begin{abstract}
A paleomagnetic study was made on the deep-marine sediments and volcanic rocks drilled by Ocean Drilling Program Leg 126 in the Izu-Bonin forearc region (Sites 787, 792, and 793). This study evaluates the sense and amount of the tectonic drift and rotation associated with the evolution of the Philippine Sea Plate and the Izu-Bonin Arc. Alternating-field and thermal demagnetization experiments show that most of the samples have stable remanence and are suitable for paleomagnetic studies. Paleomagnetic declinations were recovered by two methods of core orientation, one of which uses a secondary viscous magnetization vector of each specimen as an orientation standard, and the other of which is based on the data of downhole microresistivity measurement obtained by using a formation microscanner. Oligocene to early Miocene samples show $10^{\circ}$ to $14^{\circ}$ shallower paleolatitudes than those of the present. Middle Miocene to early Oligocene samples show progressive clockwise deflections (up to $\sim 80^{\circ}$ ) in declination with time. These results suggest large northward drift and clockwise rotation of the Izu-Bonin forearc region since early Oligocene time. Considering previous paleomagnetic results from the other regions in the Philippine Sea, this motion may reflect large clockwise rotation of the whole Philippine Sea Plate over the past 40 m.y.
\end{abstract}

\section{INTRODUCTION}

One of the prime objectives of Ocean Drilling Program (ODP) Leg 126 was to reveal the volcanic and tectonic history of the IzuBonin Arc since its initiation in early Cenozoic time. To achieve this aim, Sites 787, 792, and 793 (Figs. 1 and 2) were drilled in the forearc basin, and hundreds of meters of sedimentary and volcanic sequences were recovered at each site. Their ages, which ranged from the early Oligocene to the Quaternary) were determined by means of biostratigraphic studies on the ship. In Holes 792E and 793B, a new tool for downhole microresistivity measurements, the formation microscanner (FMS), was used, and downhole sedimentary and tectonic structures on a scale of centimeters were revealed by this method (Taylor, Fujioka, et al., 1990; Pezard and Lovell, 1990).

Systematically shallower paleomagnetic inclinations have been reported by many previous paleomagnetic studies on deep-sea cores drilled from the Philippine Sea (Louden, 1977; Bleil, 1980; Keating, 1980; Keating and Herrero, 1980; Kinoshita, 1980), and on terrestrial formations of the Izu-Bonin Arc (Keating et al., 1983; Kodama et al., 1983; Koyama, 1983; Hirooka et al., 1985; Keating and Helsley, 1985; Haston and Fuller, 1991). These studies attributed the shallower inclinations to northward latitudinal movements of the Philippine Sea (PHS) Plate. Preliminary on-board paleomagnetic studies of samples from the forearc sites of Leg 126 revealed systematic downcore decreases in the remanent magnetization inclinations, which suggest a northward drift of the forearc drill sites (Taylor, Fujioka, et al., 1990).

Besides the paleomagnetic inclination, significant clockwise deflections of paleomagnetic declination were found in Eocene to middle Miocene formations in the Bonin, Mariana, and Palau islands (Larson et al., 1975; Fuller et al., 1980; Keating et al., 1983; Keating and Helsley, 1985; Kodama et al., 1983; McCabe and Uyeda, 1983; Adachi et al., 1987; Haston et al., 1988; Haston and Fuller, 1991). However, the interpretation of these declination anomalies is still debatable. Although

'Taylor, B., Fujioka, K., et al., 1992. Proc. ODP. Sci. Results, 126: College Station, TX (Ocean Drilling Program).

${ }^{2}$ Faculty of Education, Shizuoka University, 836 Oya, Shizuoka 422, Japan.

${ }^{3}$ Department of Geological Sciences, University of California at Santa Barbara, Santa Barbara, CA 93106, U.S.A.

${ }^{4}$ Borehole Research Group, Lamont-Doherty Geological Observatory, Palisades, NY 10964, U.S.A. several tectonic models have been proposed, a common consensus has not yet been achieved. One reason for the debate is that data for clockwise-deflected declinations were obtained only from islands, which have limited locations along the eastern edge of the Philippine Sea, the only exception being in the interpretation of the skewed magnetic anomalies of the West Philippine Basin (Louden, 1977; Shih, 1980). Thus, the areal extent of the region that experienced clockwise rotations of paleomagnetic vectors is still uncertain.

Two methods are possible for the azimuthal orientation of rotary drilled cores; the first uses the secondary viscous component of remanent magnetization as a standard for orientation, and the second is based on the correlation of an azimuthally oriented FMS image with a sedimentary or tectonic structure of the recovered cores. In this study, we use both methods for the azimuthal orientation of rotary drilled cores to recover paleomagnetic declinations of the forearc sites. Combining the declination and inclination data with other geological and geophysical data from the PHS Plate, we attempt to reconstruct the tectonic evolution of the Izu-Bonin-Mariana-YapPalau (Izu-Palau) arc system and the PHS Plate.

\section{SAMPLES AND MEASUREMENT}

Leg 126 forearc cores were drilled using a rotary core barrel (RCB) on Holes 787B, 792E, and 793B; an extended core barrel (XCB) on Holes 792B to 792D; and an advanced piston core barrel (APC) on Holes 792A and 793A. One to three discrete samples (7- $\mathrm{cm}^{3}$ cube or $10-\mathrm{cm}^{3}$ minicore) were collected from each section of the recovered cores except from those cores composed of gravel or with serious drilling disturbance. Most of the samples are clay, silt, sandy silt, tuffaceous silt, and nannofossil chalk, which are massive or dilutely laminated and commonly have bioturbated features. Beside these, several samples were collected from the volcanic rocks of the acoustic basement (andesitic or basaltic lava flows of Cores 126792E-71R to $-76 R$ and Cores $126-793 B-92 R$ to $-112 R$ ), and from a dolerite sill (Core 126-793B-1R). Laminations, bedding planes, and the tops and bottoms of lava flows of all the sampled horizons have nearly horizontal structures ( $\left.<10^{\circ} \mathrm{dip}\right)$. Core drifts from vertical were $<2^{\circ}$ in all horizons of each hole (Taylor, Fujioka, et al., 1990).

About 260 discrete samples were measured using the fully automated spinner (FAS) magnetometer on the ship and after the cruise (Taylor, Fujioka, et al., 1990, pp. 13-42). The noise level of the magnetometer 


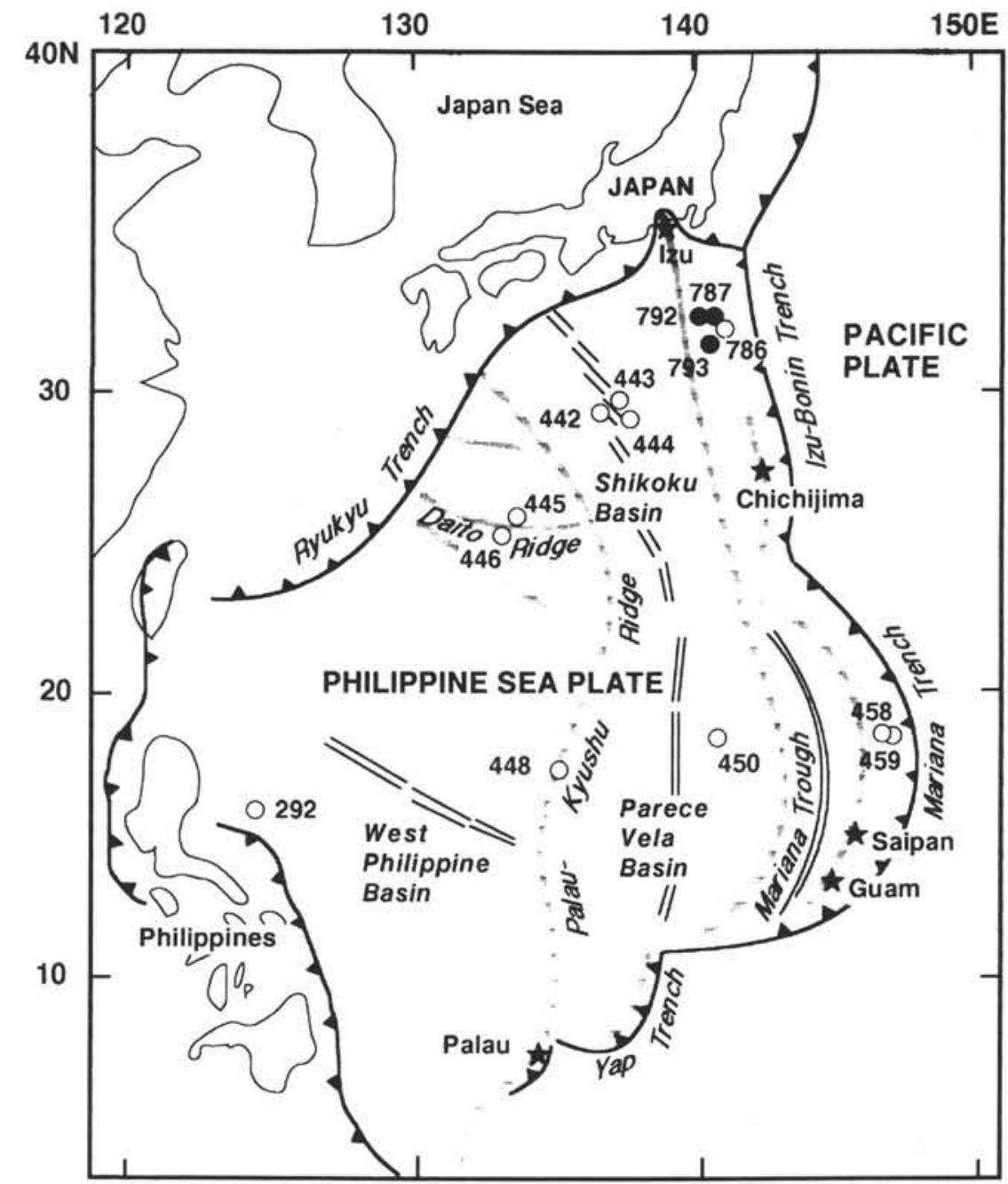

Figure 1. Tectonic features in and around the Philippine Sea at present. The thick solid line with teeth shows an active convergence boundary between plates. The thick gray line traces a ridge crest of active or nonactive volcanic arc in the Philippine Sea. Double lines show the locations of spreading centers of active or nonactive marginal basins. Sites examined by the present and previous paleomagnetic studies are shown with symbols: solid circle $=$ Leg 126 forearc site highlighted in this paper; open circle $=$ other ODP or IPOD drill sites; star $=$ onland site.

corresponds to $1 \mathrm{~mA} / \mathrm{m}$ on the ship, and to $0.1 \mathrm{~mA} / \mathrm{m}$ in the shore-based situation for a $10-\mathrm{cm}^{3}$ sample in 10-times stacking measurements.

To examine the stability of remanent magnetization of the samples and to detect the stable component of remanence, we performed alternating-field (AF) and thermal demagnetization experiments. Most of the measured samples were subjected to stepwise AF demagnetization of up to $50 \mathrm{mT}$. Several pilot samples were subjected to stepwise thermal demagnetization at the University of California at Santa Barbara, using an electronic furnace situated just outside the $2 \mathrm{G}$ cryogenic magnetometer, which enables the high-temperature measurement of samples.

\section{RESULTS}

Measured samples generally show good stability of remanent magnetization, and AF demagnetization effectively removed unstable components of remanence from many of the samples. The intensity of natural remanent magnetization (NRM) of the measured samples mainly ranges from 10 to $300 \mathrm{~mA} / \mathrm{m}$ for sediments, and from 400 to $2000 \mathrm{~mA} / \mathrm{m}$ for volcanic rocks, except for dolerite sill samples and a few tuffaceous silt samples with intensities that range from 2000 to $4000 \mathrm{~mA} / \mathrm{m}$. The median demagnetizing field (MDF) of the samples mainly ranges from 5 to $40 \mathrm{mT}$. Many of the samples have a clear stable component of remanence, which is shown by a straight line toward the origin on an orthogonal demagnetization plot (Fig. 3A). In these samples, we obtained a stable component direction by regression line analysis for at least four sublinear vector endpoints, most of which are between 25 and $50 \mathrm{mT}$ steps.

In the other samples shown in Figures $3 \mathrm{~B}$ and $3 \mathrm{C}$, we cannot define a stable component within the highest coercivity region. In the type shown in Figure 3B, the sublinear vector endpoints of higher coercivity do not align with the origin of the coordinate system; this suggests the possibility that the sample has another unknown stable component with higher coercivity. In the type shown in Figure 3C, the sample displays no sublinear alignment of vector endpoints. The samples with the features shown in Figures $3 \mathrm{~B}$ and $3 \mathrm{C}$ were rejected from the paleomagnetic discussion in the following sections. We used the included angle between the regression line anchored to the coordinate origin and the non-anchored regression line as a criterion for rejection or employment. The angle is larger than $5^{\circ}$ for the rejected samples. 


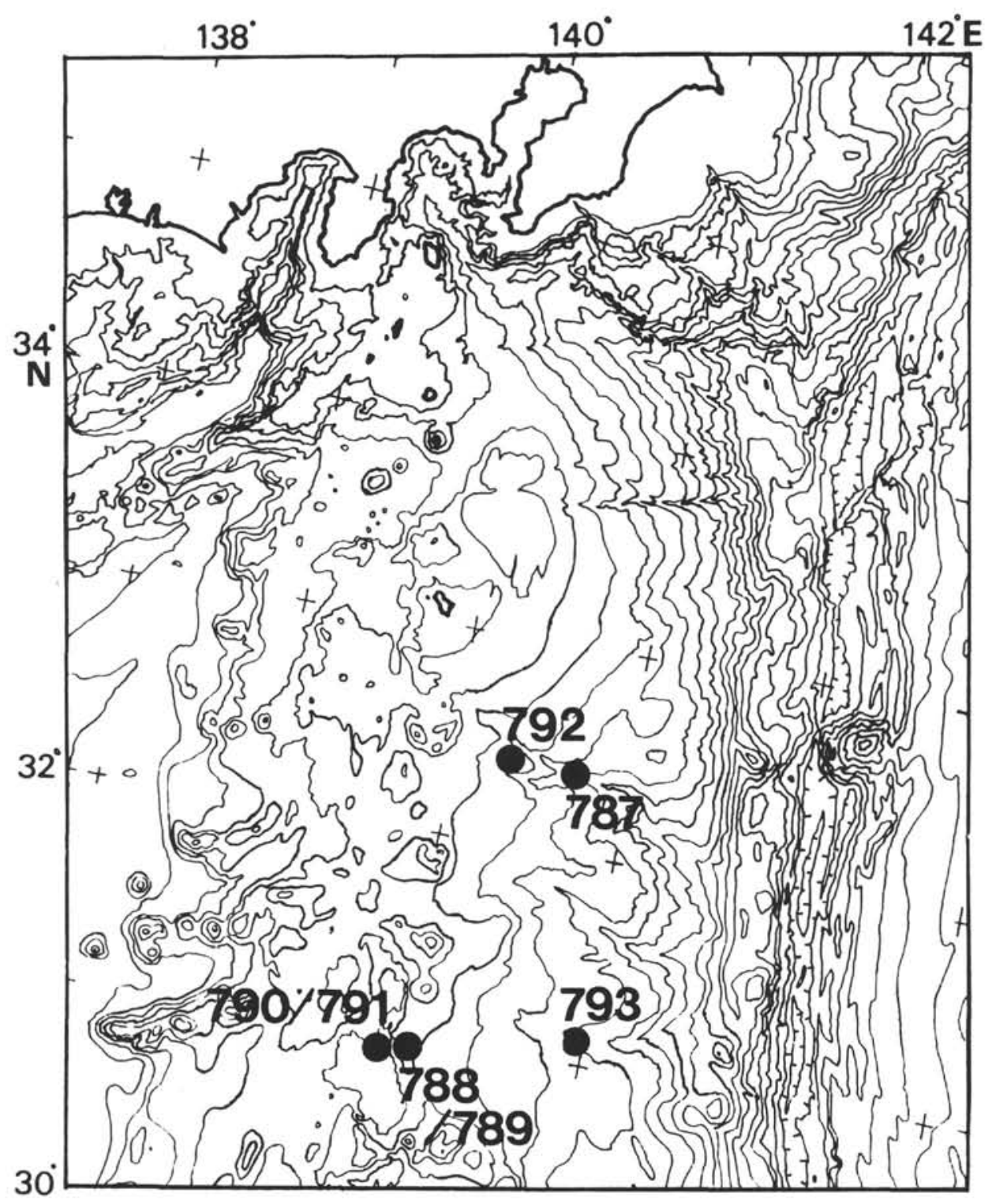

Figure 2. Topography of the northern Izu-Bonin Arc and drill sites of Leg 126. Sites 787, 792, and 793 are forearc sites. The bathymetric map, contoured at $500 \mathrm{~m}$, is by B. Taylor.

The results of stepwise thermal demagnetization on several pilot specimens are similar to those of AF demagnetization. Figure 4 illustrates the comparison between the results of stepwise $\mathrm{AF}$ and thermal demagnetizations on the same specimen. The stable component direction obtained by the AF demagnetization is consistent with that obtained by the subsequent thermal demagnetization. This shows the validity of the AF demagnetization to isolate stable directions of remanence.

To check the paleomagnetic reliability of the stable components of remanence, a conglomerate test was applied to two sections with no drilling disturbance (Sections 126-792E-61R-4 and 126-793B57R-3) that include mud clasts in debris flows (Fig. 5). Each of the two sections is situated near the base of sedimentary sections of the forearc basin, and the diagenesis is more pronounced than in the upper sedimentary sections (Taylor, Fujioka, et al., 1990). However, in the Hole 792E samples, the stable components of three mud clasts have different directions from one another, indicating that the acquisition of their remanence predates the deposition of the debris flow. The conglomerate test is positive in this case. In Hole 793B, three mud clasts have directions on the same quadrant of the stereonet, although the stable component direction of Sample 126-793B-57R-3, 69$71 \mathrm{~cm}$, is not well defined. Thus, the conglomerate test is not conclusive for this section.

In the Leg 126 forearc sites, magnetic polarities were well defined by on-board, whole-core, pass-through measurements using a $2 \mathrm{G}$ cryogenic magnetometer. Each polarity interval was correlated with the standard magnetic polarity time scale with the help of biostratigraphic studies (Taylor, Fujioka, et al., 1990). The magnetic polarities of discrete samples are concordant with the on-board results and confirm the magnetostratigraphy established during the cruise.

\section{Inclination and Paleolatitude}

The magnetic properties and remanence directions of all the samples for which the stable component of remanence can be defined by stepwise AF demagnetization are summarized in Table 1. Figure 6 shows the temporal variations of remanence inclinations in each forearc site. No tilting corrections of remanence directions were executed because of the nearly horizontal $\left(<10^{\circ}\right)$ sedimentary struc- 
A

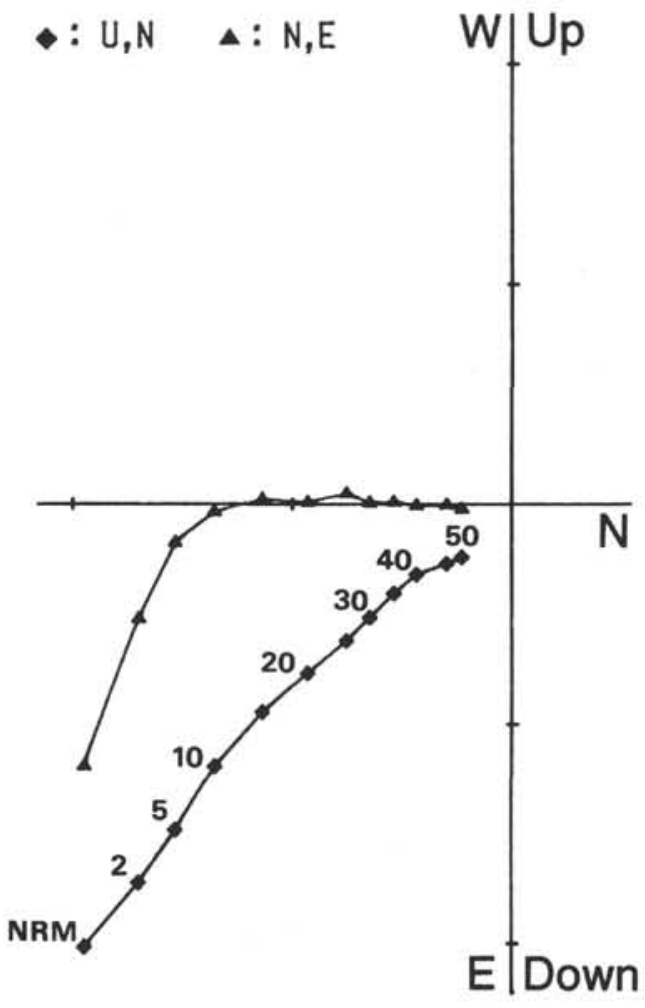

126-793B-21R-3, 17-19 cm Scale unit $=100 \mathrm{~mA} / \mathrm{m}$

\section{B}

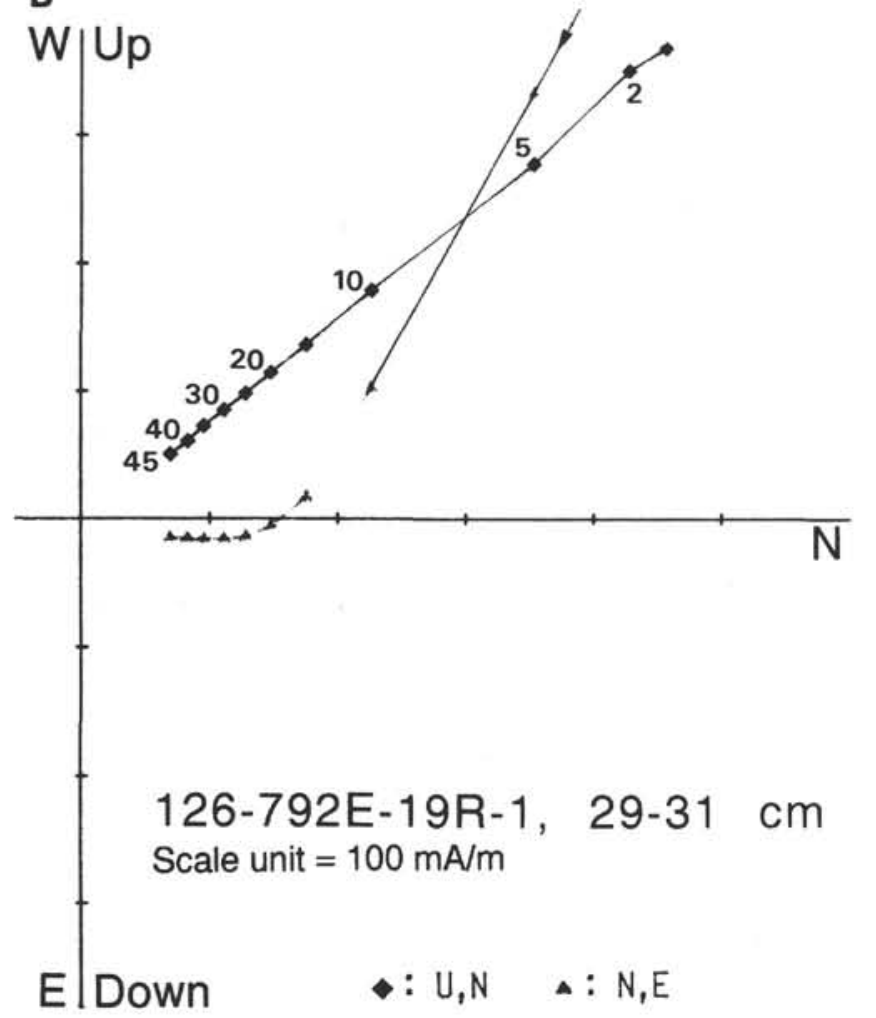

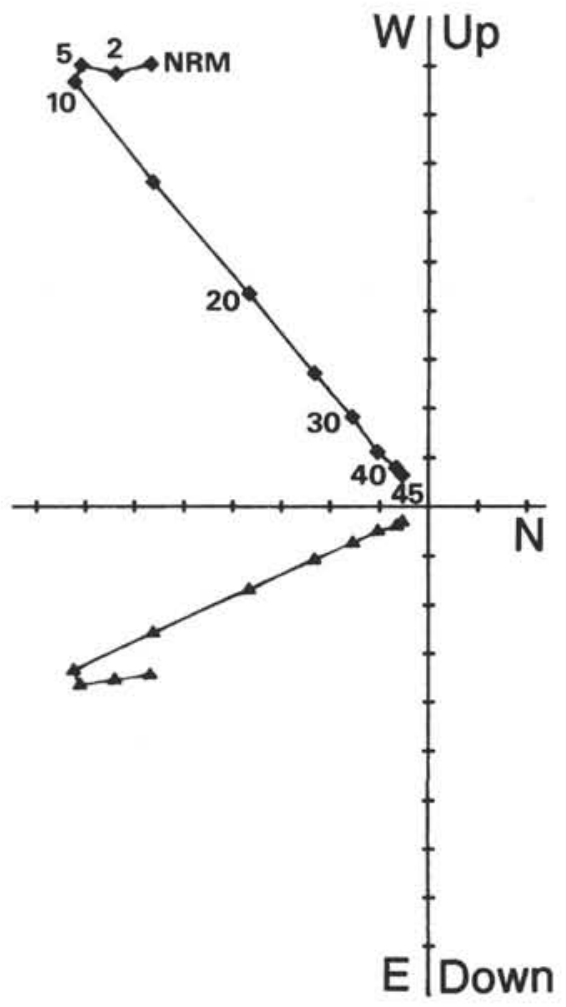

126-792E-75R-2, 81-83 cm Scale unit $=100 \mathrm{~mA} / \mathrm{m}$

C

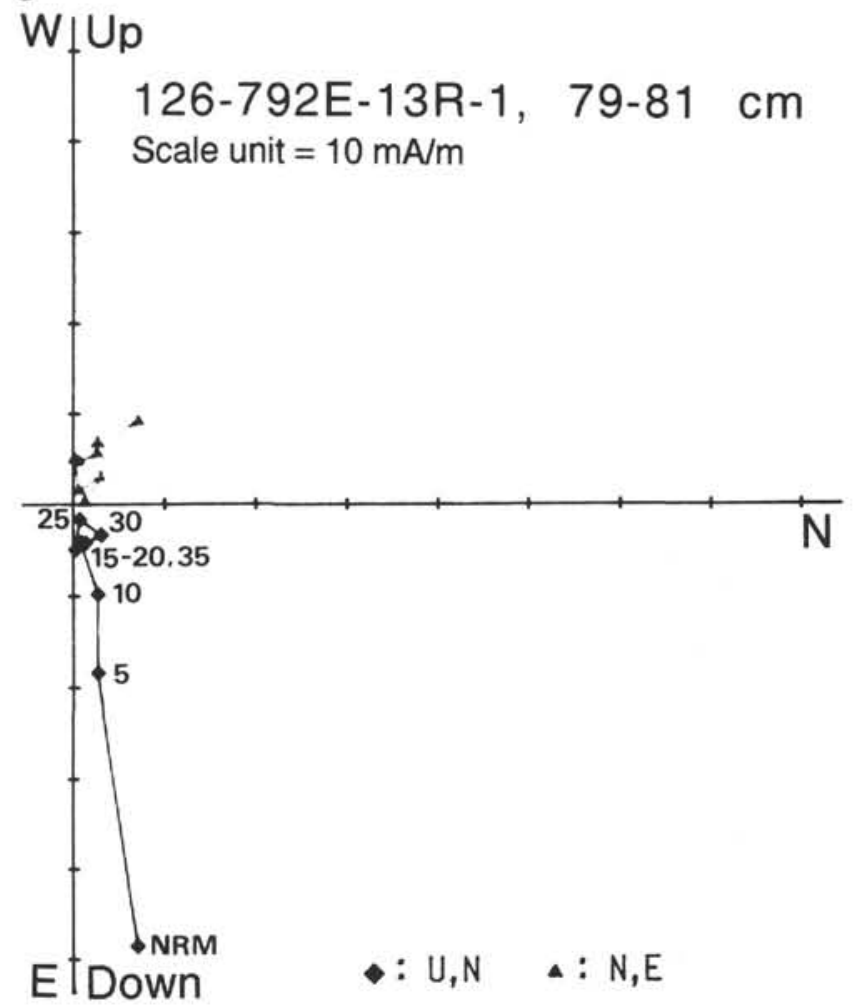

Figure 3. Typical examples of orthogonal vector endpoint diagrams showing the results of stepwise alternating-field demagnetization. For explanations of Figures $3 \mathrm{~A}-3 \mathrm{C}$, see text. 

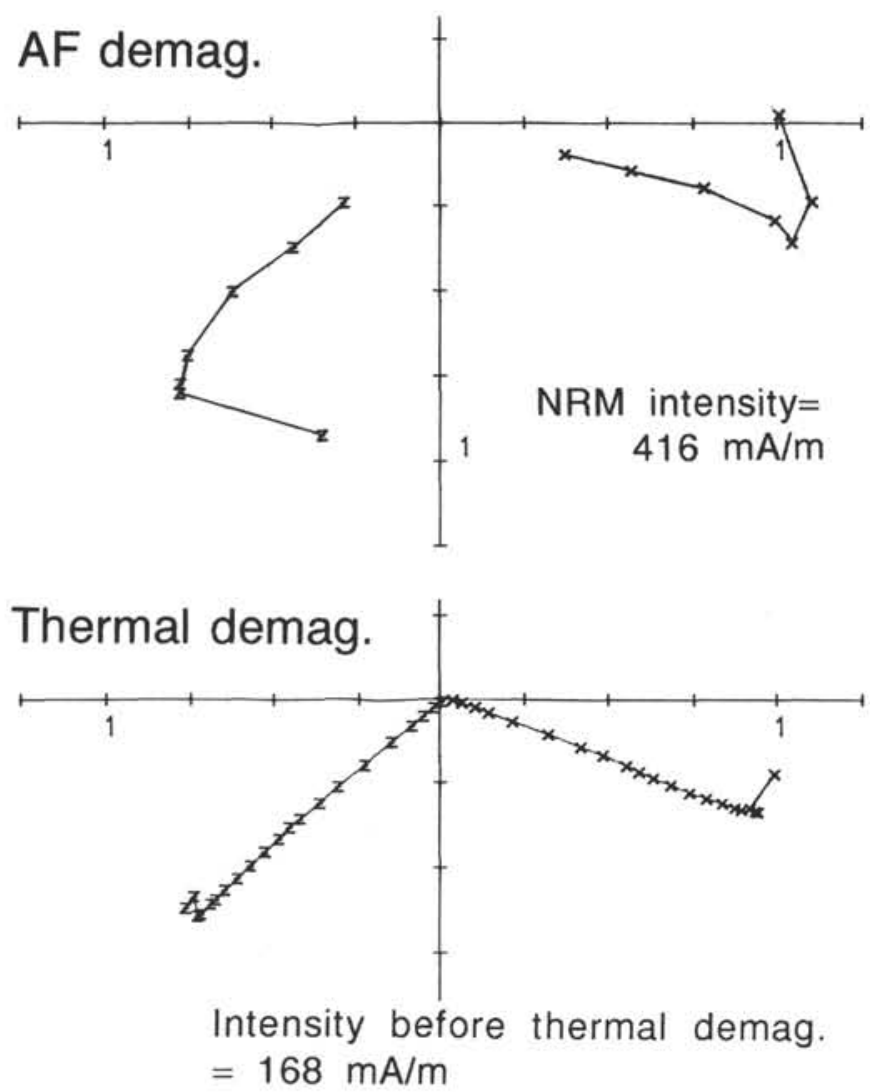

Figure 4. Example of the comparison between the results of alternating-field (AF) and thermal demagnetizations for Sample 126-792E-64R-1, 66-68 cm. The sample was first subjected to stepwise AF demagnetization of up to $50 \mathrm{mT}$ and then demagnetized thermally.

tures of the drilled cores for the intervals under consideration. Figure 6 also shows the mean inclinations determined by on-board, whole-core, pass-through measurements on archive halves of cores (Taylor, Fujioka, et al., 1990). Because current ODP policy prohibits $\mathrm{AF}$ demagnetizations beyond $15 \mathrm{mT}$ on archive halves, the wholecore pass-through data may reflect insufficient AF demagnetization to remove secondary magnetizations. The systematic difference between normal and reversed polarity data of whole-core inclinations at about 25-30 Ma for Site 793 probably resulted from this limitation in on-board magnetic cleaning. Thus, the whole-core pass-through data should only be used as an indicator of a trend as a whole.

Figure 6 shows a systematic decrease of remanence inclinations with age for the Leg 126 forearc sites. The mean inclinations and $95 \%$ confidence limits for the discrete samples are $43.5^{\circ} \pm 7.5^{\circ}$ for the late middle Miocene, $37.9^{\circ} \pm 7.2^{\circ}$ for the early Miocene, and $33.6^{\circ} \pm 3.2^{\circ}$ for the Oligocene samples. These values correspond to the latitudinal northward movement $7^{\circ}$ since the late middle Miocene, $10^{\circ}$ since the early Miocene, and $13^{\circ}-14^{\circ}$ since the Oligocene.

\section{Declination and Tectonic Rotation}

We employed two methods to determine the paleomagnetic declinations of drilled cores: (1) the use of secondary, magnetically "soft" components of remanence as a core-orientation standard; and (2) the correlation of structural or sedimentary features of drilled cores with azimuthally oriented downhole FMS images.

Land-based paleomagnetic samples often have a secondary viscous remanent magnetization (VRM) component that has a similar direction to that of the present geomagnetic field. Thus, in some cases, the direction of VRM components can be used as the magnetic north for the drilled core samples. Shibuya et al. (1991) successfully applied this method to Leg 124 cores for a paleomagnetic reconstruction of the Celebes Sea Basin.

We employed this method for samples from Sites 792 and 793. In the orthogonal demagnetization plot of each sample, we chose a secondary component with lower coercivity (e.g., samples in Fig. $3 \mathrm{~A})$, consisting of at least three sublinear vector endpoints, and calculated the direction by regression line analysis (Table 1). These soft components were detected from the vector endpoints in the steps between NRM and 10-mT AF demagnetization. Many of the inclinations of these components are positive in both Sites 792 and 793 (Fig. 7). This supports the validity of the assumption that these components reflect a "present-field" overprint.

Figures $8 \mathrm{~A}$ and $8 \mathrm{~B}$ show the stable component directions that were azimuthally oriented with respect to the "present-field" directions derived by the secondary component analysis. The azimuthally oriented directions were determined for the samples with soft-component inclinations ranging from $20^{\circ}$ to $70^{\circ}$. In spite of large dispersions, the directions from both sites seem to show semi-antipodal distributions of directions with both polarities, suggesting significant clockwise deflections in declination. Soft components of remanence are susceptible to artificial remagnetizations that can occur during drilling, storing, or cutting of cores. Actually, in the on-board paleomagnetic measurements, we found various remagnetizations of artificial origins (Taylor, Fujioka, et al., 1990). The large dispersions of the azimuthally oriented directions may be caused in part by such softcomponent remagnetizations.

The results in Figure 8 are concordant with that from the other core-orientation method using FMS images. For this orientation method, samples were taken across portions of the cores where the clear bedding has a $5^{\circ}-10^{\circ}$ dip angle and the dip direction was close to or within the plane through which the core was cut (in a few cases, the dip direction was either straight down into the core face or directly out of the core face, and was so noted). The visually determined direction and the dip angle were noted for each sample. Azimuthal orientation was then achieved by deriving the true direction of bedding dip from the FMS record and by transforming the sample coordinate dip direction to the field (true) coordinate dip direction. Only samples taken from core intervals in which the sense of dip direction was fairly constant were employed.

Figure 9 shows the azimuthally oriented stable component directions from Sites 792 and 793 using this "FMS" method. These directions show progressive clockwise declination deflection with increasing age; $34^{\circ} \pm 17^{\circ}$ for $10-12 \mathrm{Ma}, 66^{\circ} \pm 21^{\circ}$ for $27-29 \mathrm{Ma}$, and $85^{\circ} \pm 13^{\circ}$ for $30-31 \mathrm{Ma}$.

Figure 10 shows the relationship between the deflection angle of the declinations from present north illustrated in Figures 8 and 9 and age. The Site 792 and 793 Oligocene samples show predominantly clockwise (positive) deflections in declination, based on either method. The mean deflection angles of the Oligocene samples of the two forearc sites estimated by the two independent methods are statistically consistent $\left(76^{\circ} \pm 12^{\circ}\right.$ by the "FMS" method, and $86^{\circ} \pm 27^{\circ}$ by the "secondarycomponent" method). These data strongly support the interpretation that large clockwise tectonic rotation has occurred in these sites since $27 \mathrm{Ma}$. The clockwise rotation estimated from the 10-12 Ma samples of Site 792 $\left(34^{\circ} \pm 17^{\circ}\right)$ is significantly smaller than the others, although the core interval sampled is quite limited.

\section{DISCUSSION}

Figure 11 summarizes the paleolatitudes reported for the onland and marine sites by the present and previous paleomagnetic studies. Most of the results, except those from the Palau Islands, show northward latitudinal movements since Eocene-Oligocene time. Figure 12 illustrates all the paleomagnetic declinations obtained by previous and present studies. As stated above, the azimuthally ori- 


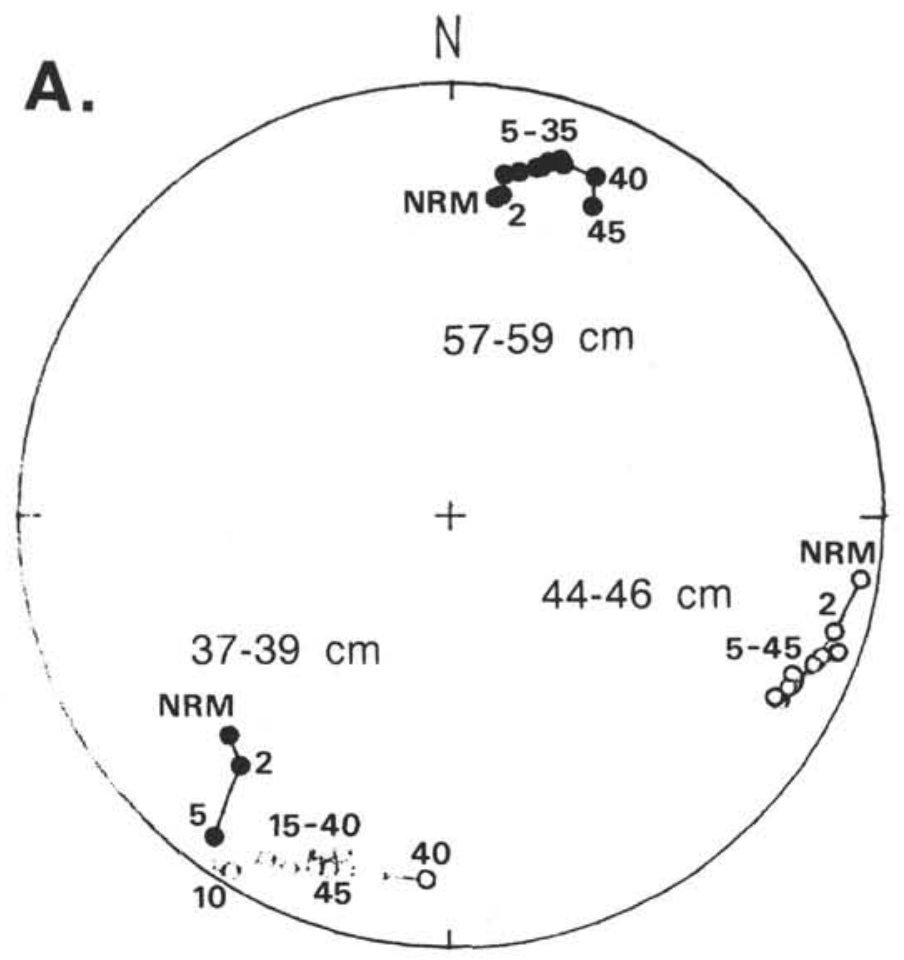

Before orientation/correction

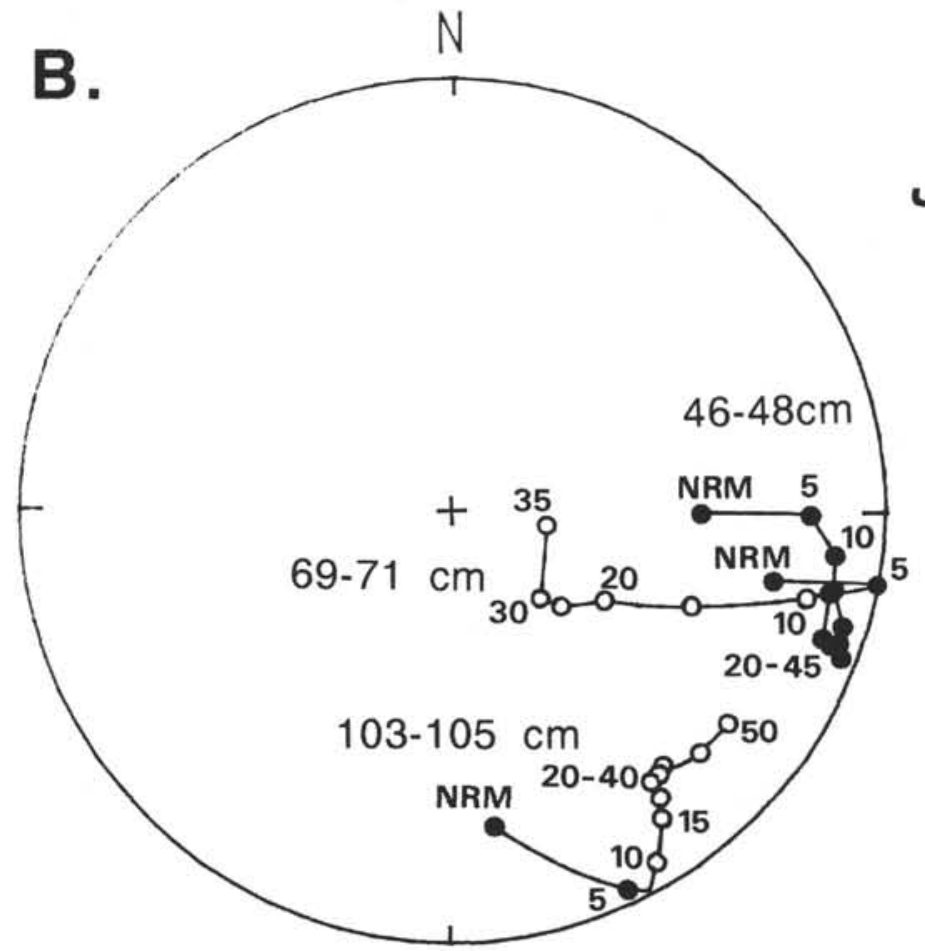

Before orientation/correction
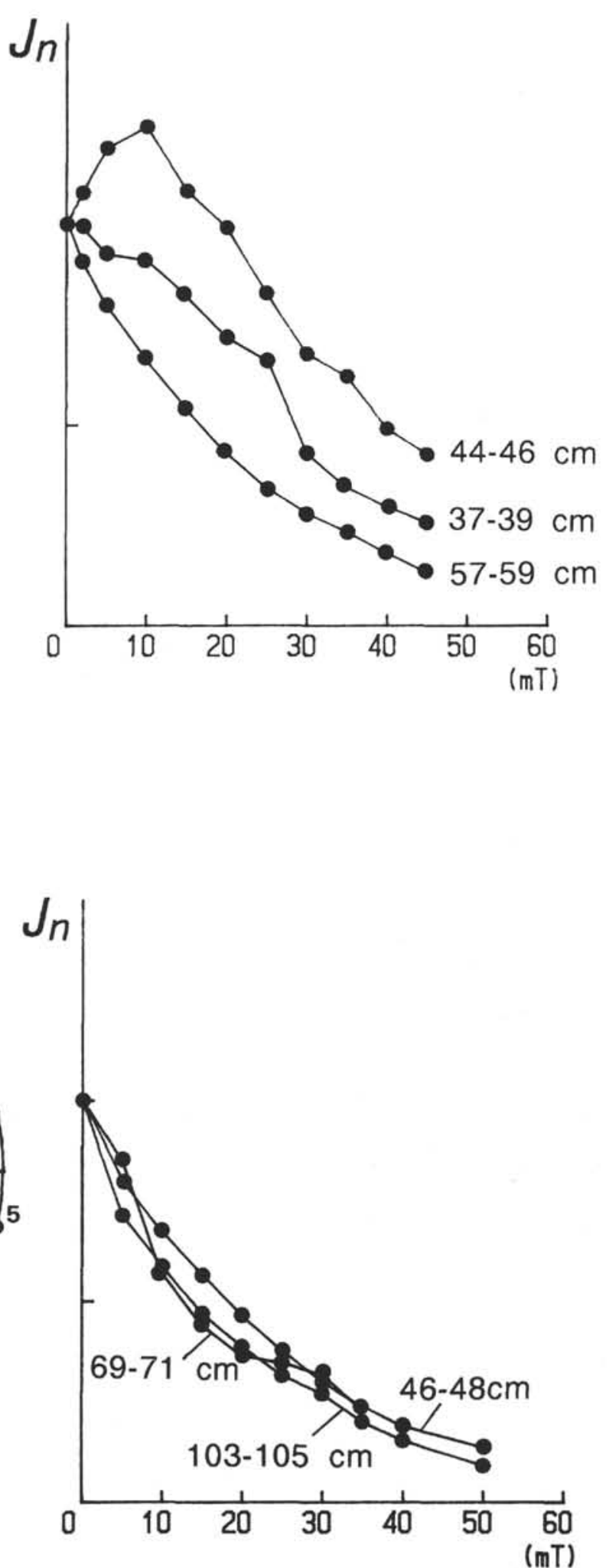

Figure 5. Results of conglomerate tests for mud-clast samples in debris-flow deposits. Each equal-area stereonet shows the changes of remanence directions of three mud clasts in the same debris-flow deposit during AF demagnetization. Solid and open circles are on lower and upper hemispheres, respectively. A. Section 126-792E-61R-4. B. Section 126-793B-57R-3. 

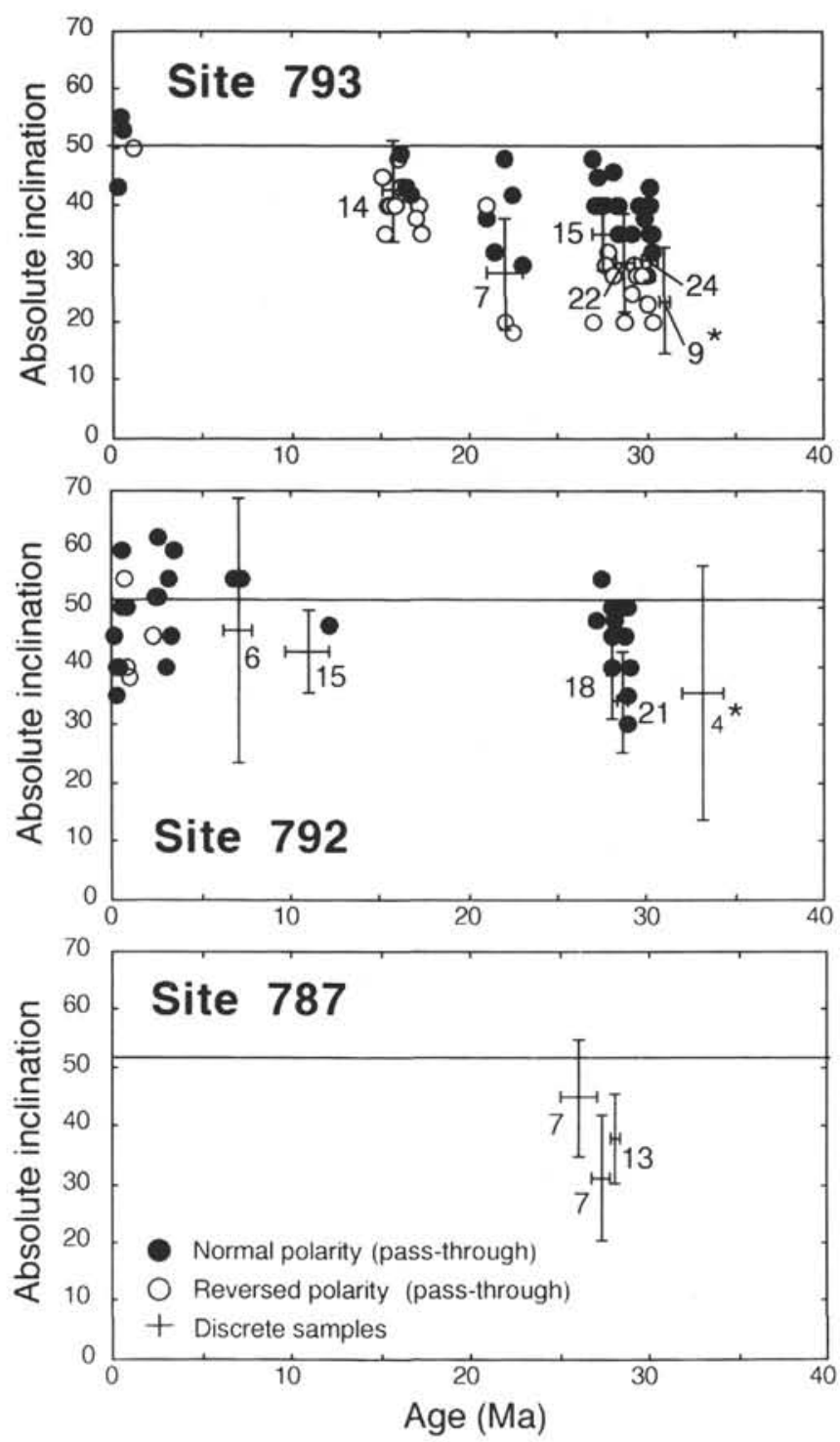

Figure 6. Relationship between remanence inclinations and their ages for each forearc site. Reversed inclinations were converted to normal ones. Cross with error bar shows the mean inclination of discrete samples after AF demagnetization. Asterisk shows the data from the volcanic basements in Sites 792 and 793. Each error bar of the mean inclination shows its $95 \%$ confidence limit. The mean inclinations and their confidence limits were calculated by Kono's method (Kono, 1980). Age errors show the age ranges of the sample horizons, except for those of volcanics, which are based on the K-Ar ages and their errors (R. Taylor, this volume). The numbers represent the number of samples. In Sites 792 and 793, mean inclinations measured with the long-core, passthrough, cryogenic magnetometer on board are shown with circles. Solid and open circles correspond to normal and reversed intervals, respectively. Longcore pass-through data from highly disturbed cores were not shown. The solid line shows the inclination of virtual geocentric dipole field for the present location of each drill site.

ented directions by the "secondary component" method and the "FMS" method are statistically consistent with each other. The large dispersion in the azimuthally oriented directions obtained by the secondary component method might result from artificial soft-component remagnetization. Thus, the azimuthally oriented directions obtained by the FMS method are employed here as directions from Leg 126 forearc sites because of their smaller confidence limits.
Soft component (Site 793)

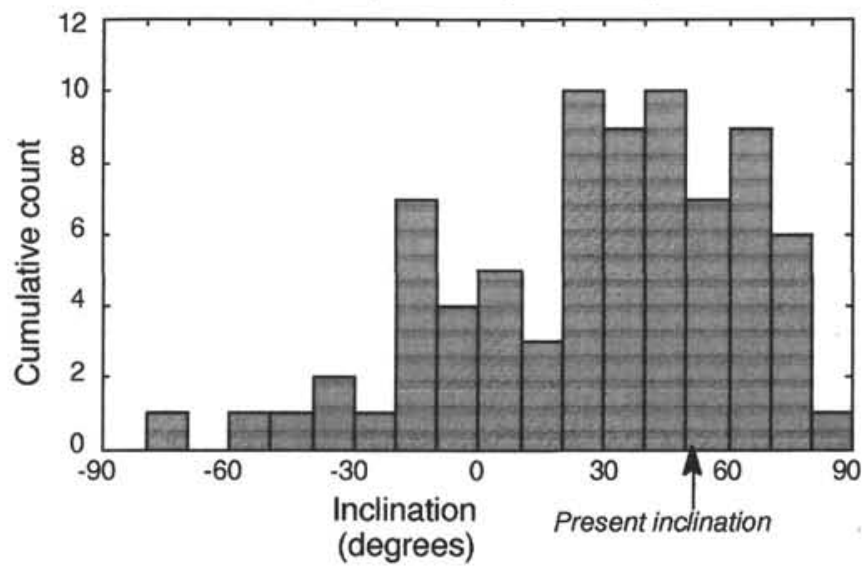

Soft component (Site 792)

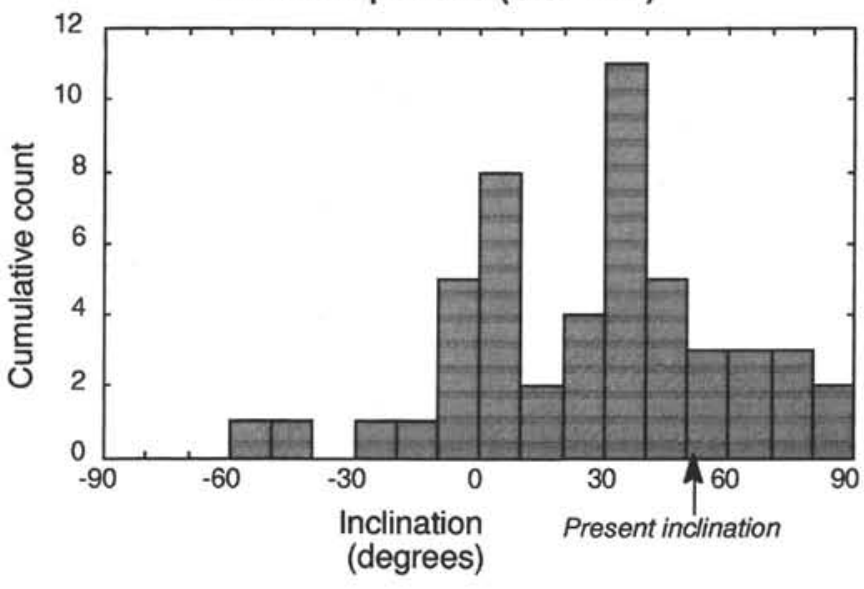

Figure 7. Histogram illustrating the distribution of soft-component inclinations of each sample for Sites 792 and 793.

Figure 12 includes the paleomagnetic interpretation of magnetic anomalies. Vacquier and Uyeda (1967) analyzed the magnetic anomalies over two seamounts near the spreading axis of the Shikoku Basin, and showed that their magnetizations were not deflected from present north (VU in Fig. 12). This suggests that no significant rotation took place in the Shikoku Basin since the latest stage of its opening about 15-17 Ma. Chamot-Rooke et al. (1989) analyzed the skewness of the magnetic anomaly of the Shikoku Basin, which indicated $<20^{\circ}$ rotation of the basin since $20 \mathrm{Ma}$ (CR in Fig. 12). In contrast with these data from the Miocene magnetic anomalies, significant clockwise deflections in declination were detected from the Eocene magnetic anomalies. Louden (1977) and Shih (1980) reported 50 $-70^{\circ}$ clockwise deflections in paleomagnetic declination from the magnetic anomalies of the West Philippine Basin (L and S in Fig. 12). Matsuda et al. (1985) analyzed the magnetic anomaly in the Chichijima Island in the Bonin Islands and found $\sim 20^{\circ}$ clockwise deflection in the paleomagnetic declination (M in Fig. 12).

In Figure 12, the Eocene-Oligocene paleomagnetic declinations consistently show clockwise deflections of $20^{\circ}-100^{\circ}$. Between the Chichijima Islands and the other Bonin islands, $70^{\circ}-80^{\circ}$ difference is present in the declination. This can be interpreted as resulting from local deformations in the Chichijima Islands based on the onland geology (S. Umino, pers. comm., 1990). As for Miocene time, samples from Palau ( 20 Ma; Haston et al., 1988), Saipan ( 12 Ma, Haston and Fuller, 1991), and Leg 126 forearc sites (10-12 Ma; Fig. 10) show $30^{\circ}-60^{\circ}$ clockwise declination deflections, whereas three paleomagnetic vectors, which were obtained from the Shikoku 
Table 1. Summary of paleomagnetic results from Sites 793, 792, and 787.

\begin{tabular}{|c|c|c|c|c|c|c|c|}
\hline $\begin{array}{l}\text { Core, section, } \\
\text { interval }(\mathrm{cm})\end{array}$ & $J_{n}$ & MDF & SoftDecl & SoftIncl & Decl & orDecl & Incl \\
\hline $\begin{array}{l}126-787 \mathrm{~B}- \\
\text { 6R-1, } \\
7 \mathrm{R}-1,11-13 \\
7 \mathrm{R}-1,58-60 \\
7 \mathrm{R}-1,40-42 \\
9 \mathrm{R}-1,40-42 \\
10 \mathrm{R}-1,86-88 \\
11 \mathrm{R}-1,17-19 \\
11 \mathrm{R}-1,142-144 \\
14 \mathrm{R}-1,51-53 \\
16 \mathrm{R}-3,114-116 \\
18 \mathrm{R}-1,23-25 \\
19 \mathrm{R}-2,143-145 \\
19 \mathrm{R}-3,84-86 \\
20 \mathrm{R}-1,70-72 \\
20 \mathrm{R}-2,102-104 \\
24 \mathrm{R}-1,74-76 \\
24 \mathrm{R}-2,42-44 \\
24 \mathrm{R}-2,87-89 \\
24 \mathrm{R}-3,89-91 \\
25 \mathrm{R}-1,123-125 \\
25 \mathrm{R}-3,8-10 \\
26 \mathrm{R}-1,32-34 \\
26 \mathrm{R}-4,51-53 \\
28 \mathrm{R}-4,60-62 \\
28 \mathrm{R}-5,106-108 \\
29 \mathrm{R}-3,50-52 \\
30 \mathrm{R}-2,42-44\end{array}$ & $\begin{array}{r}90.0 \\
128.0 \\
988.1 \\
58.7 \\
47.5 \\
2.71 \\
5.49 \\
4.17 \\
37.1 \\
147.0 \\
49.0 \\
289.0 \\
108.0 \\
425.0 \\
75.2 \\
46.0 \\
76.2 \\
48.1 \\
93.1 \\
119.0 \\
184.0 \\
211.0 \\
150.0 \\
46.5 \\
76.9 \\
103.0\end{array}$ & $\begin{array}{l}39 \\
30 \\
20 \\
37 \\
35 \\
35 \\
50 \\
23 \\
30 \\
30 \\
31 \\
37 \\
31 \\
42 \\
35 \\
46 \\
30 \\
37 \\
42 \\
32 \\
34 \\
37 \\
31 \\
23 \\
26 \\
28\end{array}$ & $\begin{array}{l}-16.7 \\
-37.1 \\
125.7\end{array}$ & $\begin{array}{l}28.7 \\
42.7 \\
67.9\end{array}$ & $\begin{array}{r}148.4 \\
-17.9 \\
-75.6 \\
-77.8 \\
44.8 \\
16.5 \\
88.6 \\
239.6 \\
109.9 \\
-45.1 \\
251.9 \\
239.7 \\
-29.3 \\
92.6 \\
258.3 \\
-67.6 \\
-83.1 \\
-63.2 \\
93.4 \\
295.7 \\
-65.6 \\
151.6 \\
-78.4 \\
-48.7 \\
-44.5 \\
30.8\end{array}$ & $\begin{array}{r}256.4 \\
7.8 \\
-33.1\end{array}$ & $\begin{array}{r}-32.0 \\
34.1 \\
37.2 \\
-43.8 \\
53.3 \\
59.4 \\
-48.8 \\
-25.9 \\
35.2 \\
40.6 \\
43.9 \\
14.9 \\
-20.7 \\
-33.0 \\
-40.3 \\
-48.0 \\
-32.7 \\
-45.7 \\
-18.2 \\
-42.1 \\
46.5 \\
47.0 \\
-26.6 \\
27.8 \\
33.0 \\
24.2\end{array}$ \\
\hline \multirow{2}{*}{\multicolumn{8}{|c|}{$126-792 \mathrm{E}-$}} \\
\hline & & & & & & & \\
\hline $\begin{array}{l}1 R-1,38-00 \\
6 R-1,104-106\end{array}$ & $\begin{array}{r}29.9 \\
1940\end{array}$ & $\begin{array}{r}0 \\
38\end{array}$ & $\begin{array}{l}-78.2 \\
196.3\end{array}$ & $\begin{array}{l}31.1 \\
43.7\end{array}$ & $\begin{array}{r}227.9 \\
96.7\end{array}$ & $\begin{array}{l}309.1 \\
-99.6\end{array}$ & 43.9 \\
\hline $9 \mathrm{R}-1,136-138$ & 129.0 & 27 & 67.6 & 83.6 & 163.8 & 96.2 & 45.0 \\
\hline $9 \mathrm{R}-3,53-55$ & 20.7 & 59 & 1.0. & 0.00 & 228.8 & & -64.4 \\
\hline $15 \mathrm{R}-1,6-8$ & 192.0 & 42 & & & 275.4 & & -49.8 \\
\hline $15 R-1,35-37$ & 6020.0 & 8 & & & 346.1 & & -31.3 \\
\hline $15 \mathrm{R}-1,86-88$ & 263.0 & 8 & & & 319.4 & & 50.7 \\
\hline $15 \mathrm{R}-2,28-30$ & 1420.0 & 8 & & & 8.0 & & 12.6 \\
\hline ITR-1, 87-89 & 124.0 & 35 & -36.6 & 63.7 & 194.5 & 231.1 & 63.7 \\
\hline $17 \mathrm{R}-2,33-35$ & 110.0 & 12 & 115.3 & 80.0 & -60.2 & -175.5 & 43.9 \\
\hline $17 \mathrm{R}-4,39-41$ & 181.0 & 55 & & & & 48.3 & -20.5 \\
\hline $18 \mathrm{R}-1,28-30$ & 61.8 & 32 & & & & 25.1 & 30.5 \\
\hline $18 \mathrm{R}-2,26-28$ & 16.7 & 59 & & & & 161.7 & -53.7 \\
\hline $18 \mathrm{R}-2,62-64$ & 46.6 & 7 & & & & 235.4 & -36.6 \\
\hline $18 \mathrm{R}-3,82-84$ & 49.3 & 42 & & & & 206.8 & -47.2 \\
\hline $19 \mathrm{R}-1,83-85$ & 96.2 & 53 & & & & 220.2 & -34.9 \\
\hline $19 \mathrm{R}-2,97-99$ & 67.5 & 24 & & & & 7.5 & 43.3 \\
\hline $20 \mathrm{R}-1,136-138$ & 45.4 & 43 & & & & 191.9 & -29.3 \\
\hline $21 \mathrm{R}-1,107-109$ & 18.4 & 75 & & & & 238.9 & -36.9 \\
\hline $22 \mathrm{R}-1,89-91$ & $\begin{array}{l}18.4 \\
183.0\end{array}$ & $\begin{array}{l}75 \\
39\end{array}$ & & & & 59.9 & 37.0 \\
\hline $23 R-1,49-51$ & $\begin{array}{l}103.0 \\
142.0\end{array}$ & 17 & & & 142.2 & 39.9 & 52.0 \\
\hline $23 \mathrm{R}-1,64-66$ & $\begin{array}{r}42.0 \\
63.8\end{array}$ & 13 & & & $\begin{array}{l}142.2 \\
131.7\end{array}$ & & 44.0 \\
\hline $23 \mathrm{R}-2,20-22$ & 132.0 & 27 & & & 122.6 & & 51.2 \\
\hline $24 \mathrm{R}-1,91-93$ & 22.7 & 25 & & & -50.7 & & 31.8 \\
\hline $30 \mathrm{R}-1,14-16$ & 21.9 & 38 & & & & 323.7 & -38.0 \\
\hline $33 \mathrm{R}-1,16-18$ & 21.3 & 21 & & & 296.5 & & 41.4 \\
\hline $33 \mathrm{R}-1,96-98$ & 139.0 & 9 & & & 162.8 & & 21.6 \\
\hline $36 \mathrm{R}-1,47-49$ & 85.0 & 28 & 12.7 & 21.8 & 100.5 & 87.8 & 52.2 \\
\hline $36 \mathrm{R}-1,65-67$ & 62.8 & 30 & 0.4 & 2.9 & 99.8 & 99.4 & 37.8 \\
\hline $36 \mathrm{R}-3,37-39$ & 41.5 & 21 & & & & 60.4 & 42.5 \\
\hline $36 \mathrm{R}-3,94-96$ & 44.3 & 27 & 25.4 & 31.6 & 158.8 & 133.4 & 49.7 \\
\hline $36 \mathrm{R}-5,23-25$ & 91.3 & 25 & 25.1 & 39.5 & 48.5 & 23.4 & 47.0 \\
\hline $37 \mathrm{R}-1,91-93$ & 81.0 & 27 & 16.4 & 33.3 & -40.9 & -57.3 & 33.5 \\
\hline $37 \mathrm{R}-2,27-29$ & 47.0 & 32 & -2.5 & 44.7 & 154.8 & 157.3 & 37.4 \\
\hline $37 \mathrm{R}-3,28-30$ & 38.6 & 32 & 21.2 & 27.7 & 126.5 & 105.3 & 8.2 \\
\hline $38 \mathrm{R}-1,59-61$ & 188.0 & 30 & 7.3 & -7.2 & 230.9 & 223.6 & 52.3 \\
\hline $38 \mathrm{R}-2,124-126$ & 126.0 & 29 & -20.5 & 39.8 & 258.1 & 278.6 & 41.6 \\
\hline $38 \mathrm{R}-3,12-14$ & 43.8 & 29 & 34.4 & 0.8 & 183.2 & 148.8 & 38.5 \\
\hline $38 \mathrm{R}-3,44-46$ & 38.3 & 32 & -56.7 & 7.3 & $\begin{array}{l}100.2 \\
104.1\end{array}$ & 160.8 & 54.8 \\
\hline $43 R-3,125-127$ & 98.5 & 34 & & & & 28.0 & 43.8 \\
\hline $43 R-4,95-97$ & 390.0 & 10 & & & & 45.8 & 21.0 \\
\hline $43 R-4,111-113$ & 120.0 & 22 & & & & 41.3 & 19.8 \\
\hline $46 R-5,33-35$ & 28.1 & 25 & & & 241.5 & & 46.2 \\
\hline $46 \mathrm{R}-5,40-42$ & 108.0 & 34 & & & 148.6 & & -3.5 \\
\hline $48 \mathrm{R}-1,56-58$ & 51.0 & 21 & & & 323.4 & & 33.7 \\
\hline $48 R-4,26-28$ & 56.6 & 32 & & & & 52.4 & 18.2 \\
\hline $48 R-4,35-37$ & 145.0 & 40 & & & & 82.9 & -23.8 \\
\hline $48 \mathrm{R}-5,32-34$ & 71.4 & 29 & & & & 82.0 & 24.4 \\
\hline $49 R-3,29-31$ & 79.2 & 35 & 185.4 & 32.8 & 6.0 & -179.4 & 45.4 \\
\hline $49 \mathrm{R}-6,104-106$ & 142.0 & 20 & 235.1 & 74.6 & 209.1 & -26.0 & 24.2 \\
\hline S0R-2, 66-68 & 261.0 & 33 & -14.2 & -19.4 & 153.1 & 167.3 & 49.8 \\
\hline $52 \mathrm{R}-1,49-51$ & 96.2 & 35 & 81.0 & 41.6 & 15.4 & -65.6 & -33.7 \\
\hline $52 \mathrm{R}-2,74-76$ & 207.0 & 21 & -27.3 & 2.7 & -19.8 & 7.5 & -35.2 \\
\hline $52 \mathrm{R}-3,112-114$ & 99.9 & 30 & -9.9 & 37.5 & 261.6 & 271.5 & -39.2 \\
\hline $52 R-4,128-130$ & 155.0 & 33 & 4.3 & 30.6 & -64.8 & -69.1 & -71.3 \\
\hline $52 R-5,64-66$ & 85.4 & 42 & 52.7 & 39.4 & -75.6 & -128.3 & -15.8 \\
\hline $54 R-3,91-93$ & 10.8 & 41 & & & & 258.7 & -28.4 \\
\hline $55 \mathrm{R}-2,44-46$ & 36.4 & 13 & & & 299.2 & & $-33,8$ \\
\hline $55 \mathrm{R}-6,32-34$ & 51.8 & 31 & 20.7 & 24.6 & 163.5 & 142.8 & 53.4 \\
\hline $58 \mathrm{R}-199-101$ & 3090 & 16 & -80.7 & -9.8 & 264.0 & 344.7 & 39.5 \\
\hline 58R-2, 109-111 & 147.0 & $\begin{array}{l}10 \\
30\end{array}$ & 46.4 & 57.8 & $\begin{array}{l}156.8 \\
156.8\end{array}$ & 110.4 & 36.2 \\
\hline $58 \mathrm{R}-3,68-70$ & $\begin{array}{l}14.0 \\
340.0\end{array}$ & 29 & $\begin{array}{l}40.4 \\
-29.7\end{array}$ & 5.0 & 247.5 & 277.2 & 8.6 \\
\hline $58 \mathrm{R}-6,7-9$ & 160.0 & 29 & 20.0 & 10.4 & 104.5 & 84.5 & 23.2 \\
\hline $71 \mathrm{R}-3,30-32$ & 758.0 & 11 & & & 299.1 & & 41.9 \\
\hline $71 \mathrm{R}-3,40-42$ & 1510.0 & 3 & -37.7 & -42.4 & 114.4 & 152.1 & 33.2 \\
\hline $75 \mathrm{R}-2,81-83$ & 1120.0 & 21 & -8.2 & -0.5 & 156.9 & 165.1 & -47.5 \\
\hline $76 \mathrm{R}-1,143-145$ & 1780.0 & 60 & 18.9 & 7.9 & 170.3 & 151.4 & -14.7 \\
\hline
\end{tabular}


Table 1 (continued).

\begin{tabular}{|c|c|c|c|c|c|c|}
\hline $\begin{array}{l}\text { Core, section, } \\
\text { interval }(\mathrm{cm})\end{array}$ & $J_{n}$ & MDF & SoftDecl & SoftIncl & Decl & orDecl \\
\hline 126-793B- & & & & & & \\
\hline 3R-1, 19-21 & 42.7 & 32 & 70.4 & 59.2 & -32.5 & -102.9 \\
\hline $3 R-2,56-58$ & 48.8 & 31 & 49.0 & 63.8 & -22.9 & -71.9 \\
\hline $3 R-3,83-85$ & 47.3 & 44 & -54.3 & 39.7 & 113.6 & 167.9 \\
\hline $4 \mathrm{R}-1,54-56$ & 63.5 & 38 & 26.7 & 25.4 & 262.9 & 236.2 \\
\hline $4 \mathrm{R}-2,15-17$ & 60.8 & 19 & 14.3 & -58.5 & 63.4 & 49.1 \\
\hline $4 \mathrm{R}-3,24-26$ & 64.5 & 24 & -69.7 & -37.4 & 156.2 & 225.9 \\
\hline $5 \mathrm{R}-2,82-84$ & 44.7 & 33 & . & . & 149.8 & 149.8 \\
\hline $5 \mathrm{R}-3,90-92$ & 64.8 & 37 & -12.2 & 75.0 & -34.5 & -22.3 \\
\hline $5 R-5,72-74$ & 58.1 & 38 & 3.0 & 64.8 & 130.9 & 127.9 \\
\hline $8 \mathrm{R}-1,84-86$ & 45.9 & 34 & -16.8 & 75.5 & 111.7 & 128.5 \\
\hline $9 \mathrm{R}-1,124-126$ & 20.9 & 30 & & & 96.0 & \\
\hline $9 \mathrm{R}-2,52-54$ & 49.1 & 31 & & & 42.6 & \\
\hline $9 \mathrm{R}-2,75-77$ & 149.0 & 45 & & & 338.0 & \\
\hline $9 \mathrm{R}-3,26-28$ & 63.7 & 48 & & & 227.3 & \\
\hline $15 R-4,78-80$ & 38.0 & 24 & & & 212.1 & \\
\hline $15 R-4,103-105$ & 63.3 & 41 & & & 34.6 & \\
\hline $15 \mathrm{R}-4,115-117$ & 4.2 & 38 & & & 89.5 & \\
\hline $16 \mathrm{R}-1,25-27$ & 15.5 & 32 & & & 46.9 & \\
\hline $16 \mathrm{R}-1,100-102$ & 22.0 & 24 & & & 272.7 & \\
\hline $18 \mathrm{R}-2,61-63$ & 60.8 & 30 & 55.8 & 31.0 & -55.4 & -111.2 \\
\hline $19 \mathrm{R}-3,107-109$ & 624.0 & 4 & 12.4 & 66.8 & -65.6 & -78.0 \\
\hline $20 \mathrm{R}-4,39-41$ & 187.0 & 8 & 1.1 & -73.3 & 42.3 & 41.2 \\
\hline $20 \mathrm{R}-4,71-73$ & 89.0 & 9 & 62.3 & 42.3 & 53.8 & -8.5 \\
\hline $20 \mathrm{R}-6,75-77$ & 66.1 & 39 & -66.2 & -11.8 & 70.6 & 136.8 \\
\hline $21 \mathrm{R}-1,71-73$ & 17.6 & 28 & 133.0 & 62.1 & 39.6 & -93.4 \\
\hline $21 \mathrm{R}-3,17-19$ & 305.0 & 14 & 111.9 & 25.4 & 182.9 & 71.0 \\
\hline $24 \mathrm{R}-4,90-92$ & 186.0 & 22 & 11. & . & 212.4 & . \\
\hline $28 \mathrm{R}-1,28-30$ & 64.1 & 32 & -9.5 & -10.7 & 66.9 & 76.4 \\
\hline $28 \mathrm{R}-4,94-96$ & 49.4 & 42 & -6.0 & 26.9 & 252.9 & 258.9 \\
\hline $29 \mathrm{R}-3,95-97$ & 117.0 & 28 & -4.0 & -16.5 & -47.6 & -43.6 \\
\hline $29 \mathrm{R}-4,87-89$ & 80.5 & 40 & 137.9 & 49.4 & 45.5 & -92.4 \\
\hline 30R-5, 103-105 & 287.0 & 33 & 101.9 & 43.4 & -135.0 & -92.4 \\
\hline $31 \mathrm{R}-1,64-66$ & 183.0 & 31 & 40.3 & 19.2 & 41.8 & 1.5 \\
\hline $3 \mathrm{IR}-4,66-68$ & 26.7 & 18 & -12.6 & 30.4 & -206.0 & -193.3 \\
\hline 31R-5, 126-128 & 195.0 & 23 & 33.0 & 27.3 & 53.4 & 20.4 \\
\hline $31 R-6,103-105$ & 186.0 & 29 & -0.6 & 67.6 & 196.3 & 196.9 \\
\hline $33 \mathrm{R}-3,39-41$ & 112.0 & 27 & -14.8 & 51.2 & -52.4 & -37.6 \\
\hline $33 R-5,77-79$ & 428.0 & 23 & & & -64.6 & \\
\hline $33 R-6,32-34$ & 98.0 & 27 & -26.7 & 33.7 & -19.0 & 7.7 \\
\hline $34 \mathrm{R}-3,91-93$ & 166.0 & 34 & 78.7 & 20.9 & 239.4 & 160.7 \\
\hline $35 \mathrm{R}-3,102-104$ & 356.0 & 20 & & & 192.9 & \\
\hline 36R-2, 71-73 & 207.0 & 12 & & & 183.9 & \\
\hline $36 R-4,8-10$ & 230.0 & 12 & & & 125.2 & \\
\hline $36 \mathrm{R}-4,37-39$ & 188.0 & 10 & & & 181.9 & \\
\hline $37 \mathrm{R}-1,88-90$ & 91.9 & 8 & & & 225.8 & \\
\hline $37 \mathrm{R}-2,89-91$ & 185.0 & 29 & & & 312.2 & \\
\hline $40 R-3,73-75$ & 45.2 & 15 & & & 251.5 & \\
\hline $42 \mathrm{R}-3,46-48$ & 70.3 & 30 & 14.4 & -5.4 & 261.8 & 247.4 \\
\hline $42 R-4,44-46$ & 132.0 & 36 & 192.7 & 59.2 & 113.0 & -79.7 \\
\hline $43 R-2,106-108$ & 85.4 & 30 & 196.2 & -32.3 & 106.1 & -90.1 \\
\hline $43 R-4,21-23$ & 11.1 & 29 & & & 119.4 & \\
\hline $46 \mathrm{R}-4,110-112$ & 38.7 & 33 & 37.9 & 3.9 & -55.6 & -93.5 \\
\hline $46 \mathrm{R}-6,41-43$ & 20.4 & 39 & 20.6 & 21.7 & 236.0 & 215.4 \\
\hline S1R-3,100-102 & 114.0 & 15 & & & 239.5 & \\
\hline $54 \mathrm{R}-2,53-55$ & 43.0 & 13 & & & 118.7 & \\
\hline $55 R-2,65-67$ & 362.0 & 21 & 21.1 & 48.3 & 71.6 & 50.5 \\
\hline $55 \mathrm{R}-2,125-127$ & 172.0 & 17 & 75.3 & 53.1 & 144.3 & 69.0 \\
\hline 56R-2, 117-119 & 446.0 & 26 & 65.0 & -14.6 & 146.4 & 81.4 \\
\hline $56 \mathrm{R}-3,128-130$ & 344.0 & 21 & & & 42.7 & \\
\hline $58 \mathrm{R}-5,51-53$ & 337.0 & 30 & 5.5 & 24.3 & 216.5 & 211.0 \\
\hline 58R-7, $104-106$ & 526.0 & 27 & 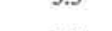 & 24. & -2.5 & (17.0. \\
\hline $65 R-5,47-49$ & 194.0 & 14 & -7.8 & 70.9 & 175.2 & 183.0 \\
\hline $65 R-7,11-13$ & 565.0 & 20 & 259.1 & -14.1 & -26.6 & -285.7 \\
\hline $66 \mathrm{R}-1,27-29$ & 258.0 & 30 & 159.0 & 28.2 & 15.6 & -143.4 \\
\hline $66 \mathrm{R}-5,13-15$ & 735.0 & 19 & 68.7 & 48.6 & 130.6 & $\begin{array}{r}-143.4 \\
61.9\end{array}$ \\
\hline $68 \mathrm{R}-1,131-133$ & 304.0 & 27 & 88.2 & $\begin{array}{r}46.0 \\
4.7\end{array}$ & 209.7 & 121.5 \\
\hline $69 \mathrm{R}-1,56-58$ & 170.0 & 26 & 78.6 & 55.2 & 128.9 & 50.3 \\
\hline $69 \mathrm{R}-3,121-123$ & 171.0 & 15 & 49.1 & 37.0 & 152.2 & 103.1 \\
\hline 69R-5. 76-78 & 75.3 & 10 & & & & 250.4 \\
\hline $70 \mathrm{R}-5,19-21$ & 174.0 & 26 & & & 328.1 & \\
\hline $71 R-2,136-138$ & 261.0 & 31 & & & & 280.2 \\
\hline 7IR- $6,28-30$ & 130.0 & 34 & & & & 278.8 \\
\hline $71 \mathrm{R}-7,18-20$ & 177.0 & 38 & & & & 242.4 \\
\hline $72 R-4,63-65$ & 139.0 & 30 & & & & 284.7 \\
\hline $72 \mathrm{R}-5,30-32$ & 37.7 & 31 & & & & 297.9 \\
\hline $74 \mathrm{R}-1,15-17$ & 193.0 & 32 & & & 54.5 & \\
\hline $75 R-4,55-57$ & 465.0 & 31 & -14.2 & 38.8 & -39.8 & -25.6 \\
\hline $78 R-4,89-91$ & 235.0 & 22 & 18.2 & 18.2 & 208.5 & 190.3 \\
\hline $78 R-6,15-17$ & 220.0 & 17 & & & 91.2 & \\
\hline $80 R-5,56-58$ & 106.0 & 18 & & & & 255.3 \\
\hline $80 R-7,14-16$ & 27.0 & 28 & & & & 239.2 \\
\hline $92 \mathrm{R}-3,11-13$ & 1050.0 & 18 & & & 28.9 & \\
\hline 99R-1, 133-135 & 1340.0 & 25 & & & 7.2 & \\
\hline $104 \mathrm{R}-2,36-38$ & 299.0 & 23 & 5.9 & 18.5 & 165.8 & 159.9 \\
\hline $104 \mathrm{R}-3,82-84$ & 427.0 & 17 & -14.9 & 40.1 & $\begin{array}{l}103.0 \\
-36.5\end{array}$ & -21.6 \\
\hline $104 R-4,46-48$ & 449.0 & 17 & 35.7 & 48.3 & 205.5 & 169.8 \\
\hline $110 \mathrm{R}-1,18-20$ & 652.0 & 18 & -4.0 & 72.6 & 227.0 & 231.0 \\
\hline $110 \mathrm{R}-2,68-70$ & 943.0 & 13 & 109.4 & 67.3 & 90.0 & -19.4 \\
\hline 110R-4, $16-18$ & 846.0 & 17 & 181.3 & 46.9 & 268.6 & 87.3 \\
\hline $112 \mathrm{R}-2,11-13$ & 1210.0 & 16 & & & 89.3 & \\
\hline
\end{tabular}

Notes: $J n=$ intensity of natural remanent magnetization; $\mathrm{MDF}=$ median demagnetizing field; SoftDecl and SoftIncl = declination and inclination of remanence component with lower coercivity (see text); Decl and Incl = declination and inclination of stable remanence component; orDecl = azimuthally oriented declination of stable remanence component (see text). Boldfaced declinations are azimuthally oriented ones using formation microscanner data (see text). 

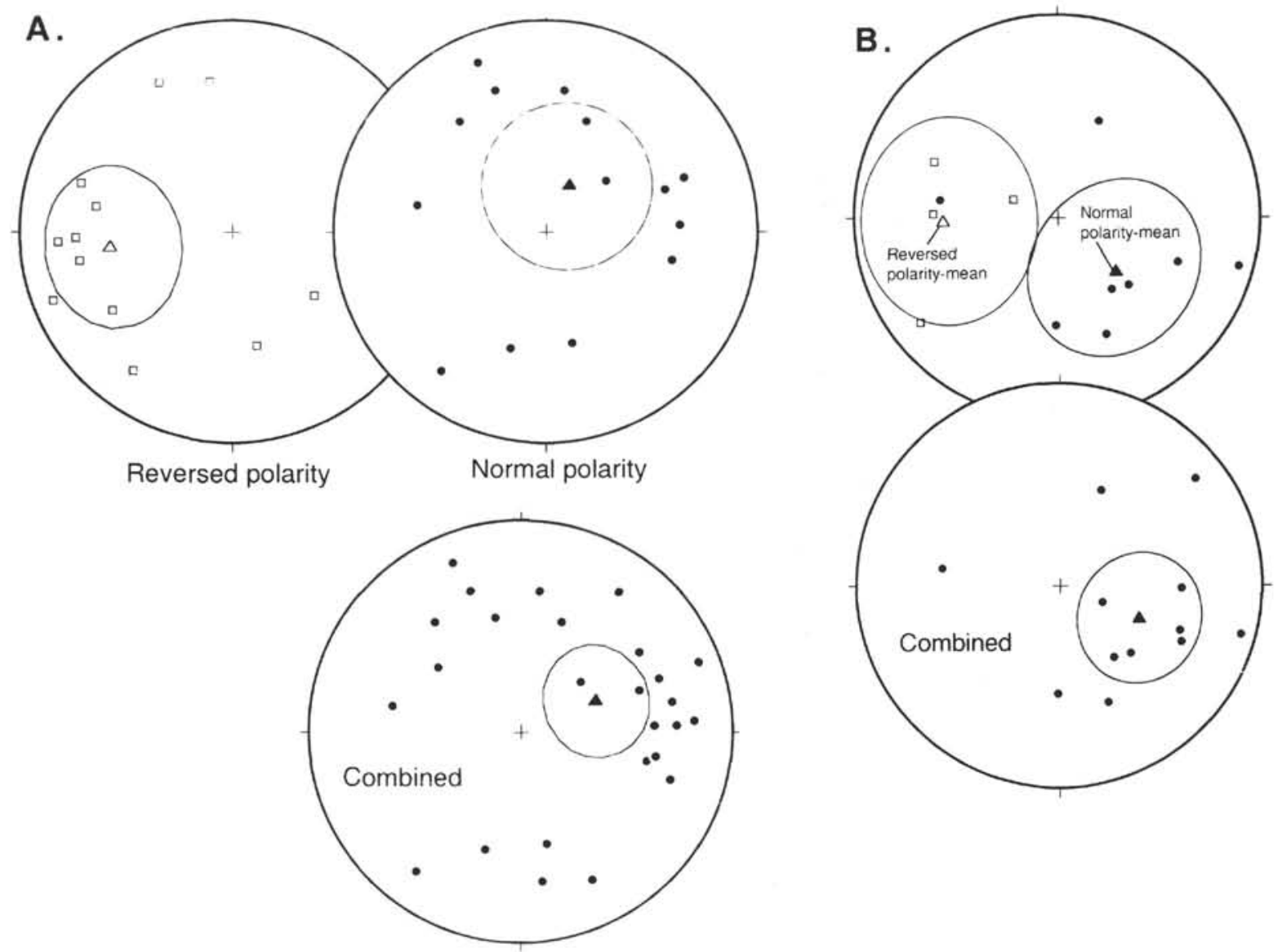

Figure 8. Equal-area projections showing azimuthally oriented directions of stable component of remanence, as determined using soft-component direction as an orientation standard. Solid and open symbols are on lower and upper hemispheres, respectively. Figures 8A and 8B are the results for Sites 793 and 792, respectively. Mean directions and their $95 \%$ confidence limits are also shown with triangles and associated circles.

Basin by the analysis of magnetic anomalies, show no significant deflections in declination. Koyama (1989) and Haston and Fuller (1991) reported no significant deflection in paleomagnetic declination from the Izu Peninsula and Saipan Island since $5 \mathrm{Ma}$. The three Miocene data from Palau, Saipan, and the Leg 126 forearc sites show smaller deflections than the other Eocene-Oligocene data in the same site, respectively. This and no significant declination deflection from the Pliocene-Pleistocene strata suggest the progressive clockwise rotation over the whole Izu-Palau Arc system since Oligocene time.

No significant clockwise deflections in the Shikoku Basin since 15-20 Ma appear to conflict with the significant clockwise deflections detected from the Miocene strata of Palau ( 20 Ma), Saipan ( 12 Ma), and Leg 126 forearc sites (10-12 Ma), although the limited data number for each site prevents reliable conclusions. If this conflict among the Miocene data is the case, local deformations involving tectonic rotation should be considered to explain the conflict.

Five tectonic models for the local or regional scale evolution of the Izu-Palau Arc system or of the PHS Plate have been proposed to explain their geophysical, geological, and geomorphological features (Fig. 13). Brief explanations of the models and their compatibility with the paleomagnetic data are stated and discussed below.

\section{Model 1: Anchored Slab Model}

The anchored slab model has been proposed to explain the tectonic evolution of the whole PHS Plate since its initiation (Matsuda, 1978;
Ben-Avraham and Uyeda, 1983; Uyeda and McCabe, 1983) (Fig. 13A). This model regards the location of the Izu-Palau Arc system as fixed because of slab anchoring in the mantle, and it proposes a westward opening of the Shikoku-Parece Vela Basin associated with subduction along the Ryukyu and Philippine trenches. However, this model cannot in itself explain the systematic clockwise deflections of paleomagnetic declination along the Izu-Palau Arc system illustrated in Figure 12. If the anchored slab hypothesis is correct, the Models 2 and/or 3 (following) are needed as supplements to explain the systematic deflections of paleomagnetic declination.

\section{Model 2: Arc Bending by Aseismic Ridge Collision}

This model attributes the deflections of paleomagnetic declination to oroclinal bending caused by the collision of an aseismic ridge or plateau (McCabe and Uyeda, 1983) (Fig. 13B). Although this model is concordant with some local features, such as the clockwise deflections in declination near the southern edge of the Mariana arc, where the Caroline ridge collided, the systematic clockwise deflections over the whole Izu-Palau Arc system or in the West Philippine Basin cannot be explained by this model alone.

\section{Model 3: Forearc Rotation by Oblique Subduction}

This model attributes the declination deflections to clockwise rotations of forearc regions, which are caused by sinistral shearing 


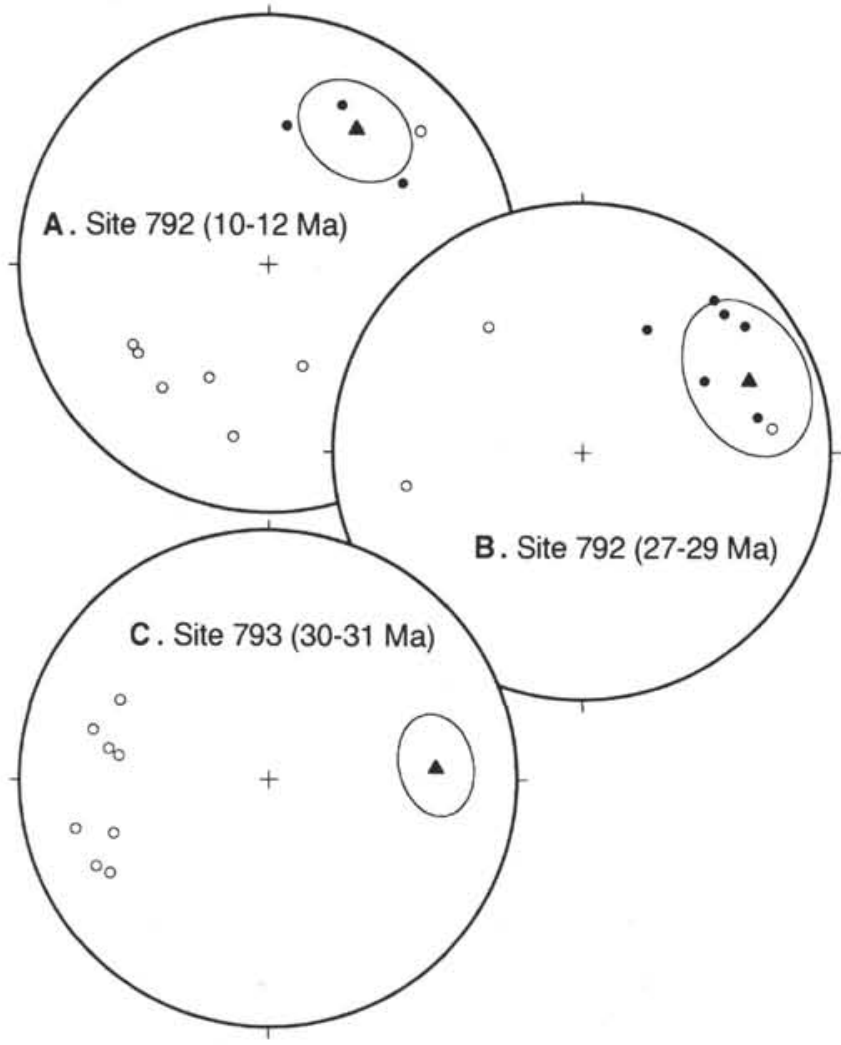

Figure 9. Equal-area projections showing azimuthally oriented directions of stable component of remanence, as determined by use of formation microscanner (FMS) data, for Site 792 middle Miocene samples (Cores 126-792E-17R to -22R); Site 792 late Oligocene samples (Cores 126-792E-30R to -54R); and Site 793 early Oligocene samples (Cores 126-793B-69R to -80R). Solid and open circles are on lower and upper hemispheres, respectively. Mean vector direction for each age (triangle) and $\alpha_{95}$ circle of confidence are also plotted. Field vectors from reversely magnetized intervals have been converted to normal polarities for each mean direction. All plotted directions have been tectonically corrected for bedding.

that resulted from the oblique subduction of the Pacific Plate beneath the Izu-Bonin-Mariana arcs (Keating et al., 1983; Kodama et al., 1983) (Fig. 13C). This model could explain the systematic clockwise declination deflections over the whole Izu-Palau forearc region, provided that sinistral oblique subduction and associated deformations occurred along the Izu-Palau arc system. However, no geomorphological or geological evidence for such sinistral deformations in the forearc regions has been reported so far. Moreover, this model cannot explain the clockwise rotation of the West Philippine Basin.

\section{Model 4: Arc Rotation by Trench Retreating}

The retreating trench model (Karig, 1975; Kobayashi and Isezaki, 1976; Seno and Maruyama, 1984) is an alternative model for the tectonic evolution of the whole PHS Plate (Fig. 13D). In contrast to the anchored slab model, this model proposes the successive seaward opening of the backarc basins in the Philippine Sea, associated with the seaward retreat of the Izu-Bonin-Mariana arc-trench system. Such arc retreats can give rise to arc rotations, if the retreat rates are not spatially uniform. According to Seno and Maruyama (1984), the amount of clockwise rotation angle based on this model since the Eocene is $30^{\circ}-50^{\circ}$ for the Izu-Bonin Arc, and $30^{\circ}$ for the West Philippine Basin, respectively. However, these angles are too small to explain the paleomagnetic observations in Figure 12.

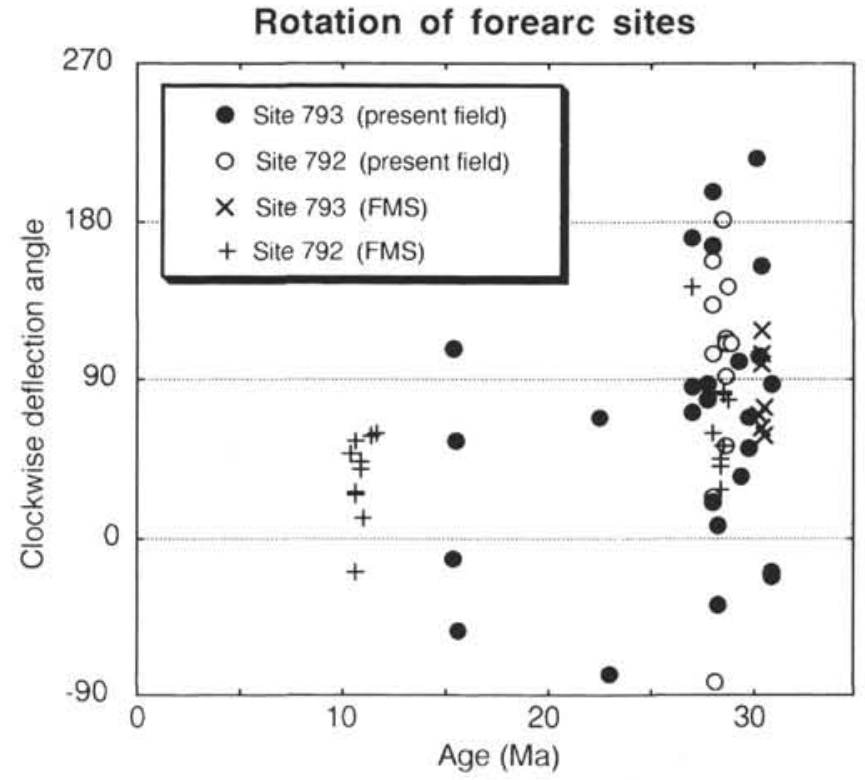

Figure 10. Relationship between azimuthally oriented declinations of remanence and their ages. Vertical axis shows the clockwise deflection angle from geographic north. Filled circles = results obtained by the "secondary component" method using a "present-field" overprint. Plus signs = results obtained by the "FMS" method using azimuthally oriented downhole FMS images.

\section{Model 5: Rotation of the Whole PHS Plate}

This model proposes the clockwise rotation of the whole PHS Plate (Keating and Helsley, 1985; Adachi et al., 1987; Haston et al., 1988; Haston and Fuller, 1991). If we do not take the three declination data from the Shikoku Basin into consideration, systematic clockwise deflections in declination over the whole Izu-Palau Arc system and the West Philippine Basin are consistent with Model 5. The progressive increase in clockwise deflections of paleomagnetic declinations over the Izu-Palau Arc system stated above can be interpreted as a manifestation of the progressive clockwise rotation of the whole PHS Plate over the past 40 m.y. Moreover, the observed paleomagnetic inclinations are well explained by this model. Few changes in paleomagnetic inclinations from Palau have occurred since the early Oligocene (Fig. 11). This suggests that the northward drift of the PHS Plate has a rotational component, and that the pivot of the rotation is located near the Palau Islands.

As stated earlier, if we take all the data including those from the Shikoku Basin into consideration, the conflict between the Miocene paleomagnetic declinations from the Shikoku Basin and those from Palau, Saipan, and the Leg 126 forearc sites can be explained only by the local clockwise rotations over these sites since Miocene time. However, the cause/mechanism of these local clockwise rotations (Model 2 or 3, or other mechanism) is not definable from the available data. Even in this case, large clockwise deflections in the West Philippine Basin require clockwise rotation of the whole PHS Plate before the opening of the Shikoku-Parece Vela basins.

Therefore, whether the data from the magnetic anomalies in the Shikoku Basin are considered or not, rotation of the whole PHS Plate (Model 5) should be required to explain the present paleomagnetic data. If we use the Miocene data from the Shikoku Basin, Model 5 plus local deformation is a most valid model, although the cause or mechanism of the local deformation is unclear.

Figure 14 shows two possible reconstructions of the PHS Plate at 17 and $27 \mathrm{Ma}$ based on Model 5, taking all the available geomorphological, geological, and geophysical data into consideration. 


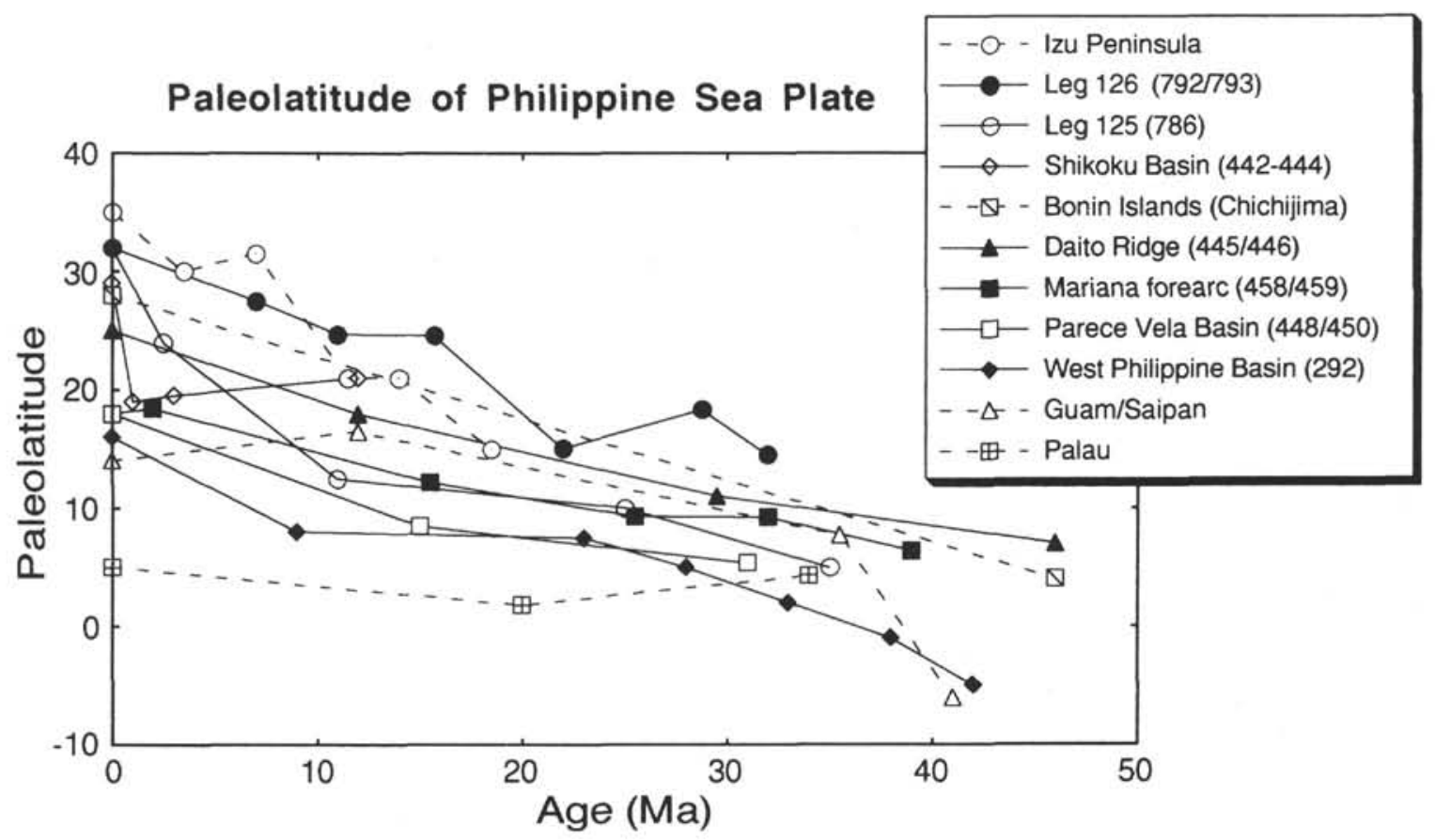

Figure 11. Summary of paleolatitudes from Leg 126 forearc sites (discrete samples from Fig. 6) and from other regions in the Philippine Sea, which are the Izu Peninsula (Hirooka et al., 1985; Koyama, 1988), Leg 125 forearc site (R. Haston, pers. comm., 1990), Shikoku Basin (Kinoshita, 1980), Bonin Islands (Keating et al., 1983; Kodama et al., 1983), Daito Ridge (Kinoshita, 1980), Mariana forearc (Bleil, 1980), Parece Vela Basin (Keating, 1980; Keating and Herrero, 1980), West Philippine Basin (Louden, 1977), Guam and Saipan islands (Haston and Fuller, 1991), and Palau Islands (Haston et al., 1988).

Model 5-1 is the reconstruction based on all the paleomagnetic data, except for those from the Shikoku Basin, and hypothesizes progressive clockwise rotation of the whole PHS Plate, whereas Model 5-2 regards the Shikoku Basin data as substantial constraints on the evolution of the PHS Plate. Model 5-2 requires local-scale deformations to explain the clockwise deflections in paleomagnetic declination over the Izu-Palau Arc system. The age constraints of backarc basins for these reconstructions are from Louden (1977), Mrozowski and Hayes (1979), Hussong and Uyeda (1981), Chamot-Rooke et al. (1987), and Kimura (1990). The radiometric ages of arcs and paleoarcs are after Meijer et al. (1983) and Tsunakawa (1985).

\section{$27 \mathrm{Ma}$}

The configuration of the PHS Plate at this time was estimated by closing the Shikoku and Parece Vela basins and the Mariana Trough, which are <30-Ma backarc basins. In Model 5-1, the clockwise rotation of the whole PHS Plate started at about this time (Fig. 14A). This estimate is based on the results that the Oligocene paleomagnetic declinations from Palau, Guam, and the Leg 126 forearc sites are similar to those from the West Philippine Basin. In contrast with this, in Model 5-2, the rotation of the West Philippine Basin should have ceased before the early stage of the Shikoku Basin opening (Fig. 14B). The opening of the Shikoku and Parece Vela basins started at about $30 \mathrm{Ma}$ and lasted to $15 \mathrm{Ma}$. Associated with the initiation of the Shikoku Basin opening, the present Izu-Bonin forearc basin was formed as an intra-arc rift and a thick sedimentary succession filled the rift until $27 \mathrm{Ma}$ (Taylor, Fujioka, et al., 1990).

In the southwest Japan forearc, the sedimentation and formation of an accretionary prism from Jurassic time had ceased in the period between 21 and $17 \mathrm{Ma}$, and major uplifting and tilting (Takachiho Orogeny) resulted in the development of large angular unconformities
(Sakai, 1988; Hibbard and Karig, 1990). This can be explained by the initiation of strong mechanical coupling between the hot and buoyant lithosphere of the young Shikoku Basin and the southwest Japan forearc. Sakai (1988) proposed the Chilean-type subduction (Uyeda and Kanamori, 1979) of the Shikoku Basin lithosphere beneath the southwest Japan forearc to explain the Takachiho Orogeny, although his model is based on the anchored slab model (Model 1). Hibbard and Karig (1990) explains the orogeny by the initiation of collision of the buoyant Shikoku Basin with the southwest Japan margin.

\section{$17 \mathrm{Ma}$}

This time corresponds to the latest stage of the Shikoku Basin opening. In both reconstructions, the configurations of the paleoRyukyu and paleo-Izu-Bonin trenches were estimated by closing the Okinawa and Mariana troughs, which opened later than this time. The configuration of plate boundaries around Japan is after the reconstruction by Niitsuma (1988). In Model 5-1, the clockwise rotation of the whole PHS Plate still lasted at this time (Fig. 14A).

This time also corresponds to the early stage of Japan Sea basin opening (Pisciotto et al., 1989; Tamaki et al., 1989). At about $15 \mathrm{Ma}$, the rapid fan-shaped opening of the Japan Sea caused $\sim 56^{\circ}$ clockwise rotation of the whole southwest Japan Arc (Otofuji et al., 1986). At the time of this rotation, the southwest Japan forearc regions thrust up onto the northern margin of the Shikoku Basin, and voluminous silicic magmatism occurred along the southwest Japan forearc (Takahashi, 1986). This event may correspond to the change of regional stress field in the southwest Japan from N-S tension to N-S compression at about $15 \mathrm{Ma}$ (Tsunakawa, 1986). This strong coupling between the southwest Japan forearc and the Shikoku Basin may also be responsible for the clockwise rotation of the Shikoku Basin and the whole PHS Plate (Niitsuma and Akiba, 1985). However, in Model 


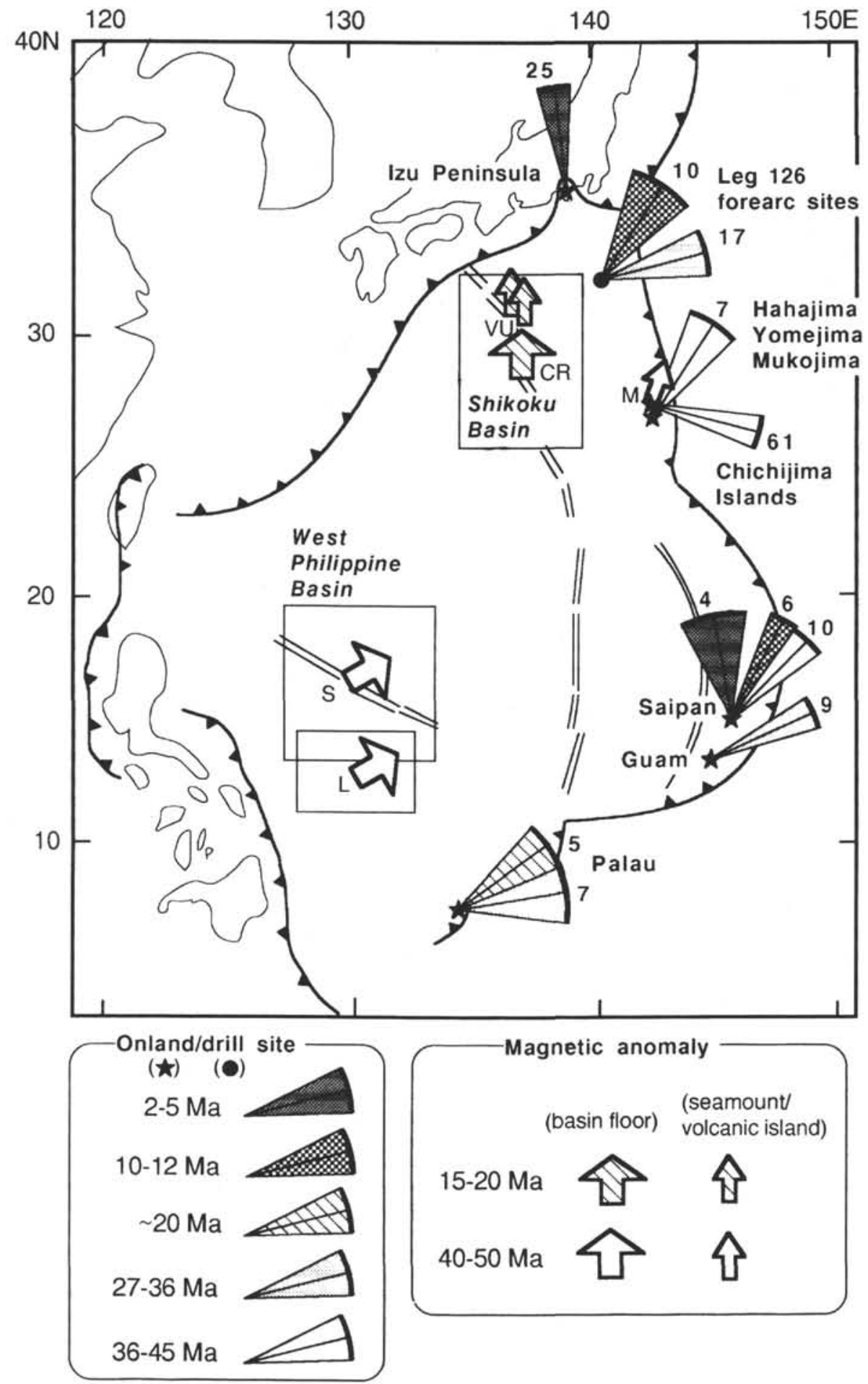

Figure 12. Summary of the directions of paleomagnetic declination from onland and marine sites in the Philippine Sea. Stars represent data from onland sites, where the mean direction of declination and its $95 \%$ confidence limit are shown with a fan-shaped symbol. The numbers on the figure represent the number of sampling sites. Onland declination data are from Bonin Islands (Keating et al., 1983; Kodama et al., 1983), Guam and Saipan islands (Haston and Fuller, 1991), and Palau (Haston et al., 1988). Each mean direction of azimuthally oriented remanence declination and its $95 \%$ confidence limit from Leg 126 drilled cores (this study) is also shown with a fan-shaped symbol. Numbers show the number of samples. The confidence limits for onland and marine sites were calculated after Damarest (1983). Arrows show the paleomagnetic declinations calculated from the magnetic anomaly skewness of marginal basins (large arrows) or of seamounts or volcanic islands (small arrows). L (Louden, 1977) and S (Shih, 1980) are from the West Philippine Basin. VU (Vacquier and Uyeda, 1967) and CR (Chamot-Rooke et al., 1989) are from the Shikoku Basin. M (Matsuda et al., 1985) is from Chichijima Island in the Bonin Islands. Rectangles show the area where the magnetic anomalies of marginal basins were analyzed. Other symbols are the same as in Figure 1. 


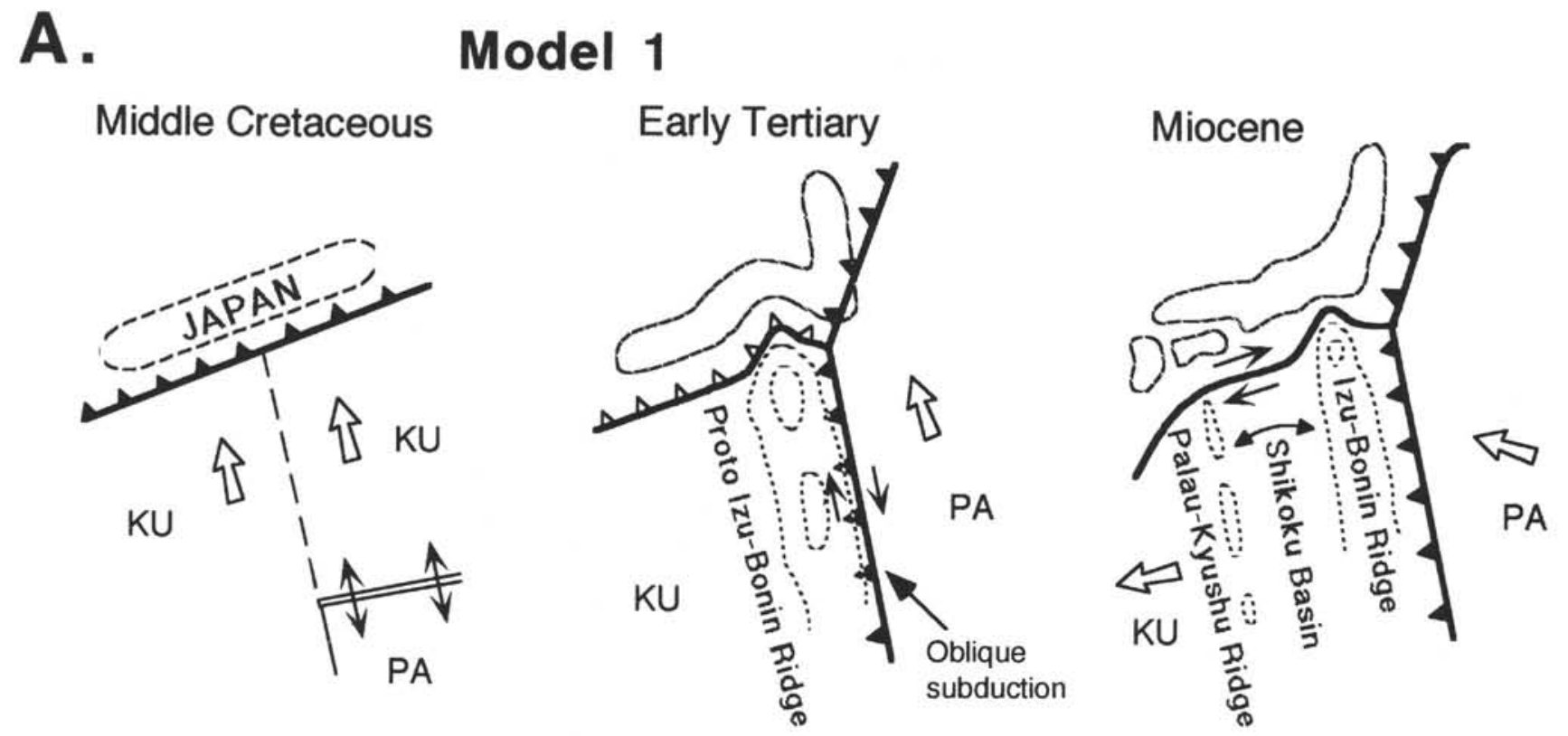

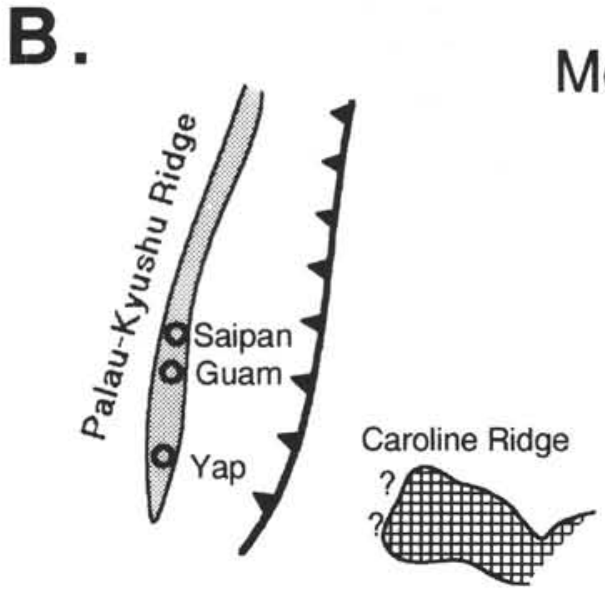

Eocene-Oligocene

Model 2

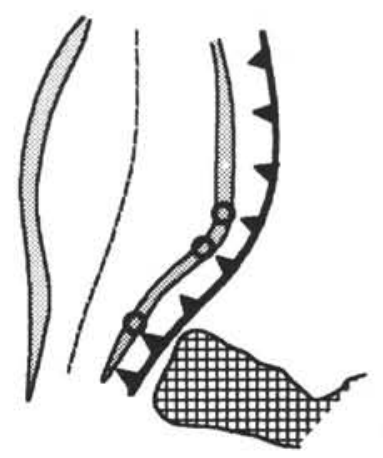

early-middle Miocene

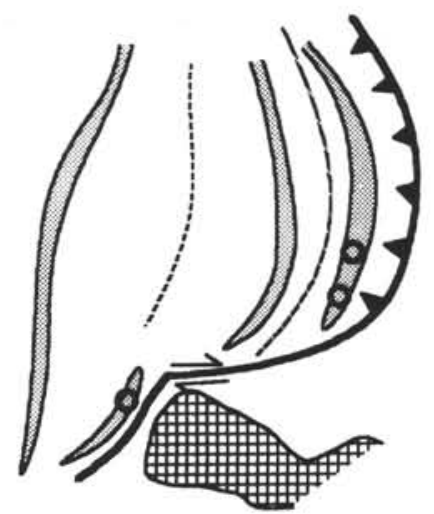

late Miocene-Holocene

Figure 13. Models for explaining the evolution of tectonic features of the Izu-Palau Arc system or the whole Philippine Sea Plate. A. Anchored slab model for the tectonic evolution of the Philippine Sea Plate (Matsuda, 1978). B. Model of oroclinal arc bending caused by collision of an aseismic ridge or plateau (McCabe and Uyeda, 1983). C. Model of forearc rotation by sinistral shearing caused by oblique plate subduction (Kodama et al., 1983). D. Example of a retreating trench model for the tectonic evolution of the Philippine Sea Plate (Seno and Maruyama, 1984).

5-2, such late timing of the PHS Plate rotation would conflict with the lack of significant skewness in the magnetic anomalies of the Shikoku Basin (Fig. 12).

In Model 5-2, the clockwise deflections of the Oligocene paleomagnetic vectors (27-36 Ma vectors in Fig. 12) in the Izu-Palau Arc system do not conflict with the lack of significant declination deflections in the Miocene data from the Shikoku Basin. Thus, the Oligocene-deflected declinations can be explained either by local deformation or by rotation of the whole PHS Plate. In the former case, the rotation of the West Philippine Basin should have preceded the local deformation; whereas in the latter case, the rotations of the deflected Oligocene vectors and the West Philippine Basin should have simultaneously occurred between 20 and 27 Ma. Figure 14B shows the former case.

\section{CONCLUSIONS}

Leg 126 drilled three sites (Sites 787, 792, and 793) in the Izu-Bonin forearc basin, and paleomagnetic measurements of recovered sediments and volcanic rock samples have been conducted to detect the tectonic movements of the Izu-Bonin forearc region. Stable remanence directions of early Oligocene to early Miocene samples show significant shallower inclinations than those of the present, indicating northward latitudinal translation of these forearc sites $\left(7^{\circ}\right.$ since the late middle Miocene, $10^{\circ}$ since the early Miocene, and $13^{\circ}-14^{\circ}$ since Oligocene time). Declinations of stable remanence recovered by two different core-orientation methods show significant clockwise declination deflections, indicating large clockwise rotations of the Izu-Bonin forearc region since the early Oligocene 
C.

\section{Model 3}

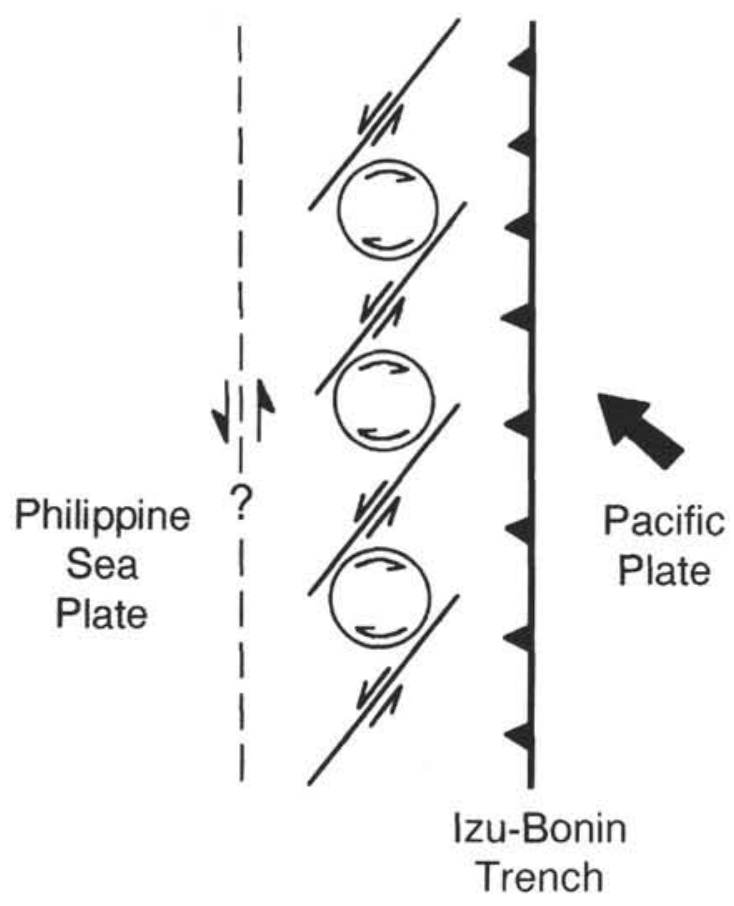

D.

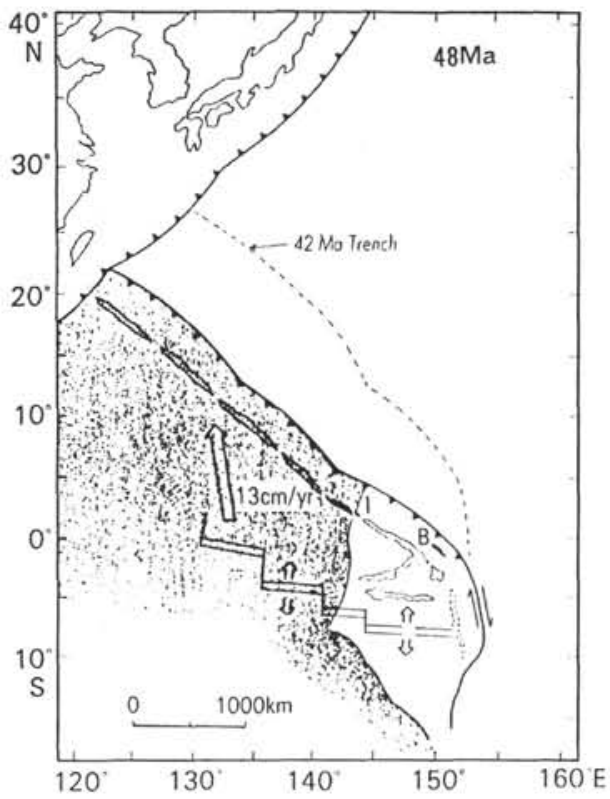

Model 4
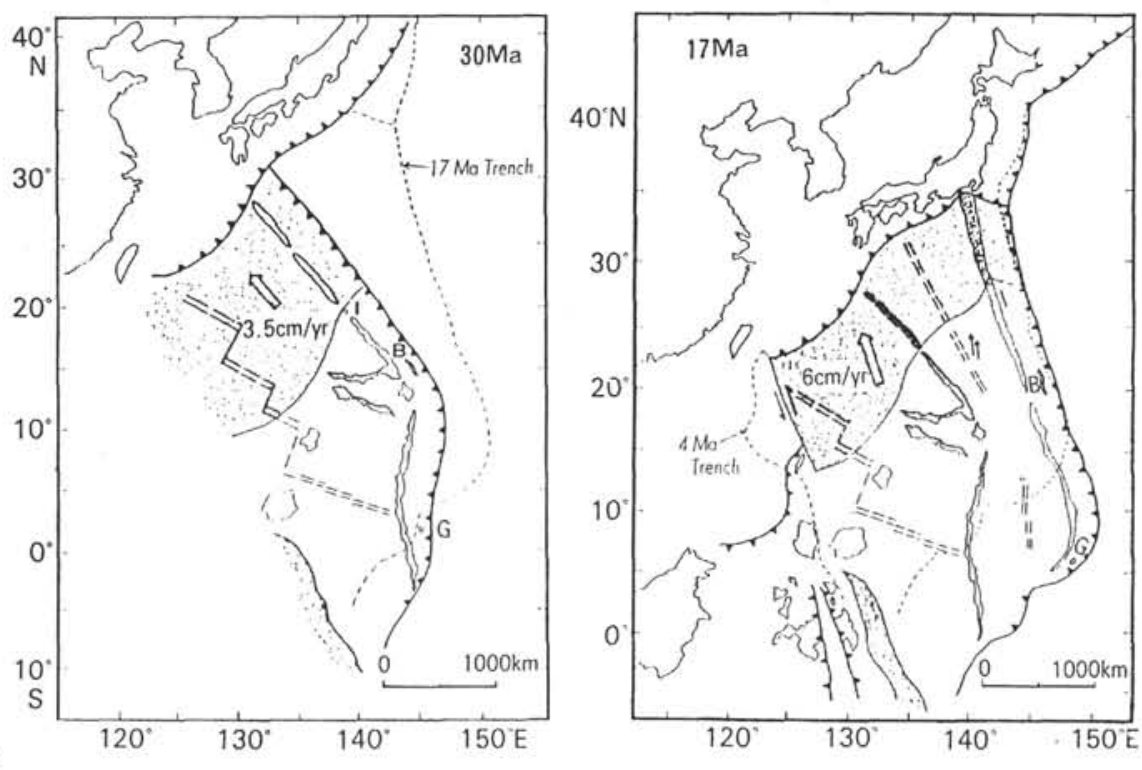

Figure 13 (continued). 


\section{A. Model 5-1}
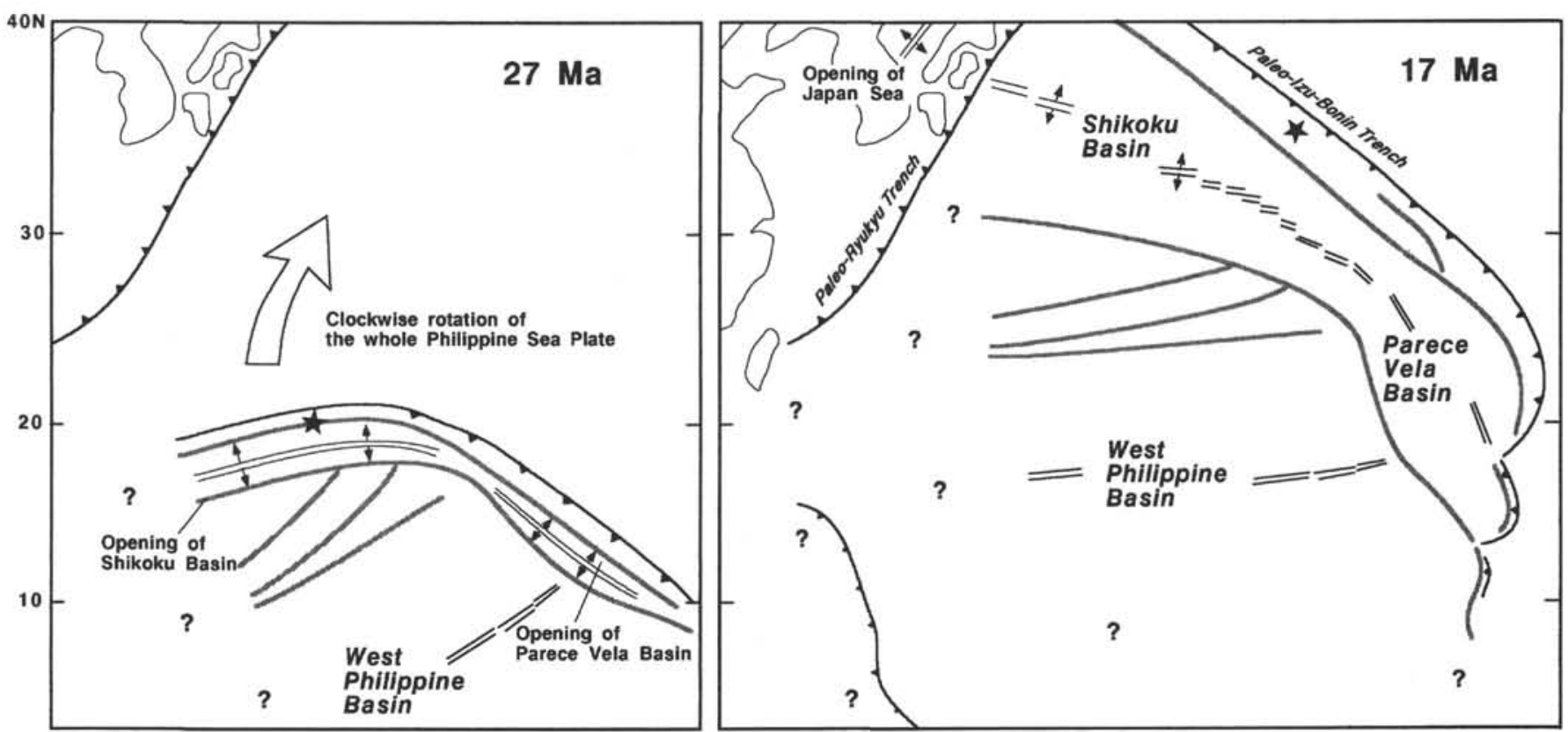

\section{B. Model 5-2}

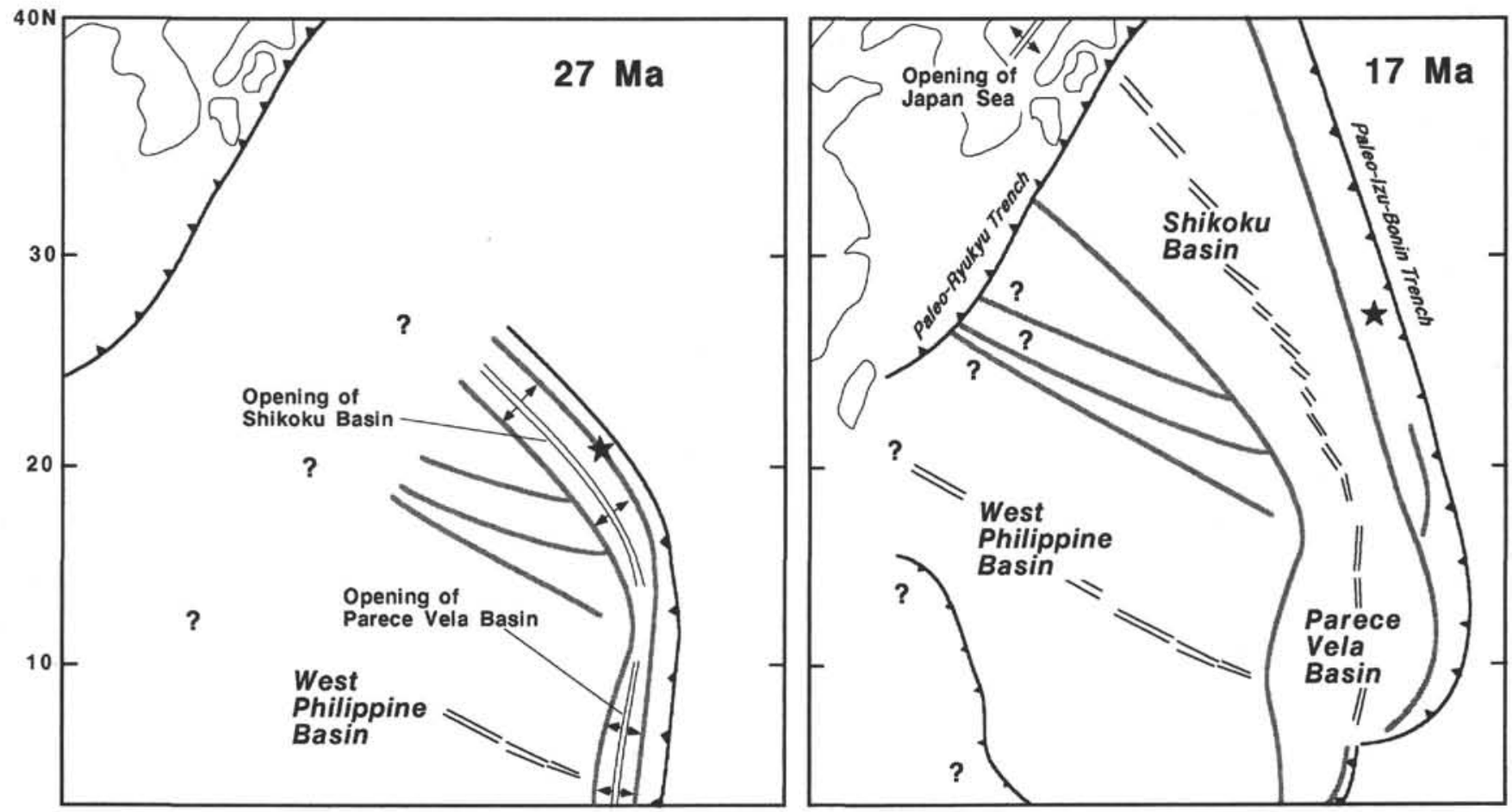

Figure 14. Reconstruction maps of the tectonic evolution of the Philippine Sea Plate at 17 and 27 Ma based on Model 5-1 (A) and Model 5-2 (B). Star shows the approximate paleolocation of Leg 126 forearc sites. Other symbols are the same as in Figure 1. The longitudinal axis is not definable. For further explanation, see text. 
$\left(76^{\circ} \pm 12^{\circ}\right.$ by the FMS method, and $86^{\circ} \pm 27^{\circ}$ by the secondary component method).

Combining our paleomagnetic data with previous paleomagnetic results from the other regions in the Philippine Sea, we propose two possible models for the tectonic evolution of the PHS Plate that involve the large clockwise rotation and northward translation of the whole PHS Plate. One model attributes the clockwise deflections in paleomagnetic declination to the rotation of the whole PHS Plate, whereas the other model combines the whole PHS rotation with local deformations. Determination of the better model depends on further acquisition of paleomagnetic data, particularly from Miocene deposits or magnetic anomalies in the PHS region.

Because both models involve large motion of the PHS Plate, various tectonic events caused by interplate coupling are expected to have occurred around the circum-PHS regions. Although many of the major tectonic events in the southwest Japan arc could be explained by our models, the compatibility of our models with the onland geology of the other circum-Philippine Sea regions awaits a continued refinement of the models in future papers.

\section{ACKNOWLEDGMENTS}

We thank all the shipboard scientists, marine technicians, and the other JOIDES Resolution crew who supported this study. We are particularly grateful to the helpful and brave co-chiefs (Drs. Kan Fujioka and Brian Taylor) and staff scientist (Tom Janecek). We also thank Wendy Autio and Bettina Domeyer, who supported our onboard laboratory works. M. Koyama thanks Keisuke Takagi for his support on shore-based paleomagnetic measurements. Appreciation is also owed to Drs. Tetsuzo Seno, Kazuto Kodama, and Brian Taylor for critically reviewing the manuscript.

\section{REFERENCES}

Adachi, Y., Inokuchi, H., Otofuji, Y., Isezaki, N., and Yaskawa, K., 1987. Rotation of the Philippine Sea Plate inferred from paleomagnetism of the Palau and the Yap islands. Rock Mag. Paleogeophys., 14:72-74.

Ben-Avraham, Z., and Uyeda, S., 1983. Entrapment origin of marginal seas, In Hilde, T.W.C., and Uyeda, S. (Eds.), Geodynamics of the Western Pacific. Am. Geophys. Union, Geodyn. Ser., 91-104.

Bleil, U., 1980. Paleomagnetism of Deep Sea Drilling Project Leg 60 sediments and igneous rocks from the Mariana region. In Hussong, D. M., Uyeda, S., et al., Init. Repts. DSDP, 60: Washington (U.S. Govt. Printing Office), 855-873.

Chamot-Rooke, N., Renard, V., and Le Pichon, X., 1987. Magnetic anomalies in the Shikoku Basin: a new interpretation. Earth Planet. Sci. Lett., 83:214-228.

Chamot-Rooke, N., Tamaki, K., and Kobayashi, K., 1989. Deskewed magnetic profiles of the Shikoku Basin and the past kinematics of the Philippine Sea Plate. Eos, 70:1365-1366. (Abstract)

Damarest, H. H., Jr., 1983. Error analysis for the determination of tectonic rotation from paleomagnetic data. J. Geophys. Res., 88:4321-4328.

Fuller, M., Dunn, J. R., Green, G., Lin, J.-L., McCabe, R., Toney, K., and Williams, I., 1980. Paleomagnetism of Truk Islands, eastern Carolines and of Saipan, Marianas. In Hayes, D. E. (Ed.), The Tectonic and Geologic Evolution of Southeast Asian Seas and Islands. Am. Geophys. Union, Geophys. Monogr. Ser., 23:235-245.

Haston, R., and Fuller, M., 1991. Paleomagnetic data from the Philippine Sea Plate, and their tectonic significance. J. Geophys. Res., 96:6073-6098.

Haston, R., Fuller, M., and Schmidtke, E., 1988. Paleomagnetic results from Palau, West Caroline islands: a constraint on Philippine Sea Plate motion. Geology, 16:654-657.

Hibbard, J. P., and Karig, D. E., 1990. Alternative plate model for the early Miocene evolution of the southwest Japan margin. Geology, 18:170-174.

Hirooka, K., Takahashi, T., Sakai, H., and Nakajima, T., 1985. Northward drift of the Izu Peninsula, central Japan. In Nasu, N., Kobayashi, K., Uyeda, S., Kushiro, I., and Kagami, H. (Eds.), Formation of Active Ocean Margins: Tokyo (Terra Sci. Pub.), 775-787.

Hussong, D. M., and Uyeda, S., 1981. Tectonics in the Mariana arc: results of recent studies, including DSDP Leg 60. Oceanol. Acta (Suppl.), $4: 203-212$.
Karig, D. E., 1975. Basin genesis in the Philippine Sea. In Karig, D. E., Ingle, J. C., Jr., et al., Init. Repts. DSDP, 31: Washington (U.S. Govt. Printing Office), 857-879.

Keating, B., 1980. Paleomagnetic study of sediments from Deep Sea Drilling Project Leg 59. In Kroenke, L., Scott, R., et al., Init. Repts. DSDP, 59: Washington (U.S. Govt. Printing Office), 523-532.

Keating, B., and Helsley, C. E., 1985. Implications of island arc rotations to the studies of marginal terranes. J. Geodyn., 2:159-181.

Keating, B., and Herrero, E., 1980. Paleomagnetic studies of basalts and andesites from Deep Sea Drilling Project Leg 59. In Kroenke, L., Scott, R., et al., Init. Repts. DSDP, 59: Washington (U.S. Govt. Printing Office), 533-543.

Keating, B., Kodama, K., and Helsley, C. E., 1983. Paleomagnetic studies of the Bonin and Mariana island arcs. In Shimozuru, D., and Yokoyama, I. (Eds.), Arc Volcanism: Physics and Tectonics: Dordrecht, The Netherlands (D. Riedel), 243-259.

Kimura, M., 1990. Genesis and formation of the Okinawa Trough, Japan. Mem. Geol. Soc. Jpn., 34:77-88. (in Japanese with English abstract)

Kinoshita, H., 1980. Paleomagnetism of sediment cores from Deep Sea Drilling Project Leg 58, Philippine Sea. In Klein, G. deV., Kobayashi, K., et al., Init. Repts. DSDP, 58: Washington (U.S. Govt. Printing Office), 765-768.

Kobayashi, K., and Isezaki, N., 1976. Magnetic anomalies in the Sea of Japan and the Shikoku Basin: possible tectonic implications. In Sutton, G. H., Manghnani, M. H., and Moberly, R. (Eds.), The Geophysics of the Pacific Ocean Basin and lts Margin. Am. Geophys. Union, Geophys. Monogr. Ser., 235-251.

Kodama, K., Keating, B. H., and Helsley, C. E., 1983. Paleomagnetism of the Bonin Islands and its tectonic significance. Tectonophysics, 95:25-42.

Kono, M., 1980. Statistics of paleomagnetic inclination data.J. Geophys. Res., 85:3878-3882.

Koyama, M., 1983. Paleomagnetic evidence for northward drift and local deformations of the Matsuzaki area, Izu Peninsula, Japan. Rock Mag. Paleogeophys., 10:61-68.

1988. The past and present of the Izu Peninsula. In Aramaki, S., and Niitsuma, N. (Eds.), Site Proposals for Japanese Continental Scientific Drilling (Vol. 1): Shizuoka (Working Group on Japanese Continental Scientific Drilling), 1-32. (in Japanese)

, 1989. Paleomagnetic studies in the South Fossa Magna and adjacent areas, Japan. Mod. Geol., 14:69-86.

Larson, E. E., Reynolds, R. L., Ozima, M., Aoki, Y., Kinoshita, H., Zasshu, S., Kawai, N., Nakajima, T., Hirooka, K., Merrill, R., and Levi, S., 1975. Paleomagnetism of Miocene volcanic rocks of Guam and the curvature of the southern Mariana Island arc. Geol. Soc. Am. Bull., 86:346-350.

Louden, K. E., 1977. Paleomagnetism of DSDP sediments, phase shifting of magnetic anomalies, and rotations of the West Philippine Basin. J. Geophys. Res., 82:2989-3002.

McCabe, R., and Uyeda, S., 1983. Hypothetical model for the bending of the Mariana Arc. In Hayes, D. E. (Ed.), The Tectonic and Geologic Evolution of Southeast Asian Seas and Islands (Pt. 2). Am. Geophys. Union, Geophys. Monogr. Ser., 27:281-293.

Matsuda, J., Matsubara, Y., and Nishimura, J., 1985. The determination of "paleolongitude" and its geophysical application to the Bonin Islands. $J$. Geomagn. Geoelectr., 56:561-574.

Matsuda, T., 1978. Collision of the Izu-Bonin Arc with central Honshu: Cenozoic tectonics of the Fossa Magna, Japan. J. Phys. Earth (Suppl.), 26:S409-S422.

Meijer, A., Reagan, M., Ellis, H., Shafiqullah, M., Sutter, J., Damon, P., and Kling, J., 1983. Chronology of volcanic events in the eastern Philippine Sea. In Hayes, D. E. (Ed.), The Tectonic and Geologic Evolution of Southeast Asian Seas and Islands (Pt. 2). Am. Geophys. Union, AGU Monogr. Ser., 27:349-359.

Mrozowski, C. L., and Hayes, D. E., 1979. The evolution of the Parece Vela Basin, eastern Philippine Sea. Earth Planet. Sci. Lett., 46:49-67.

Niitsuma, N., 1988. Neogene tectonic evolution of Southwest Japan. Mod. Geol., 12:497-532.

Niitsuma, N., and Akiba, F., 1985. Neogene tectonic evolution and plate subduction in the Japanese island arcs. In Nasu, N., Kobayashi, K., Uyeda, S., Kushiro, I., and Kagami, H. (Eds.), Formation of Active Ocean Margins: Tokyo (Terra Scientific), 75-108.

Otofuji, Y., Matsuda, T., and Nohda, S., 1986. Brief review of Miocene Opening of the Japan Sea: paleomagnetic evidence from the Japan arc. J. Geomagn. Geoelectr., 38:287-294.

Pezard, P., and Lovell, M., 1990. Downhole images: electrical scanning reveals the nature of subsurface oceanic crust. Eos, 70:709. 
Pisciotto, K., Tamaki, K., and Leg 127 Shipboard Scientists, 1989. ODP Leg 127: sedimentary and oceanographic evolution of the deep sea basins of the eastern Japan Sea. Eos, 70:1366.

Sakai, H., 1988. Origin of the Misaki olistostrome belt and re-examination of the Takachiho orogeny. J. Geol. Soc. Jpn., 94:945-961. (in Japanese with English abstract)

Seno, T., and Maruyama, S., 1984. Paleogeographic reconstruction and origin of the Philippine Sea. Tectonophysics, 102:53-84.

Shibuya, H., Merrill, D. L., Hsu, V., and Leg 124 Shipboard Scientific Party, 1991. Paleocene counterclockwise rotation of the Celebes Sea-orientation of ODP cores utilizing the secondary magnetization. In Silver, E. A., Rangin, C., von Breymann, M. T., et al., Proc. ODP, Sci. Results, 124: College Station, TX (Ocean Drilling Program), 519-523.

Shih, T., 1980. Marine magnetic anomalies from the Western Philippine Sea: implications for the evolution of marginal basins. In Hayes, D. E. (Ed.), The Tectonic and Geologic Evolution of Southeast Asian Seas and Islands (Pt. 2). Am. Geophys. Union, Geophys. Monogr. Ser., 23:49-75.

Takahashi, M., 1986. "Arc" magmatism before and after the opening of the Japan Sea. Kagaku, 56:103-111. (in Japanese)

Tamaki, K., Pisciotto, K., and Leg 127 Shipboard Scientists, 1989. ODP Leg 127: tectonic synthesis of drilling results of the Japan Sea. Eos, 70:1366.
Taylor, B., Fujioka, K., et al., 1990. Proc. ODP, Init. Repts., 126: College Station, TX (Ocean Drilling Program).

Tsunakawa, H., 1985. Radiometric ages of volcanism in the Philippine Sea region. Gekkan Chikyu, 12:694-700. (in Japanese)

1986. Neogene stress field of the Japanese arcs and its relation to igneous activity. Tectonophysics, 124:1-22.

Uyeda, S., and Kanamori, H., 1979. Back arc opening and the mode of subduction. J. Geophys. Res., 84:1049-1061.

Uyeda, S., and McCabe, R., 1983. A possible mechanism of episodic spreading of the Philippine Sea. In Hashimoto, M., and Uyeda, S. (Eds.), Accretion Tectonics in the Circum-Pacific Regions: Tokyo (Terra Scientific), 291-306.

Vacquier, V., and Uyeda, S., 1967. Paleomagnetism of nine seamounts in the western Pacific and of three volcanoes in Japan. Tokyo Daigaku Jishin Kenkyusho Iho, 45:814-848.

Date of initial receipt: 2 January 1991

Date of acceptance: 24 July 1991

Ms 126B-143 